Article

\title{
Dynamics of Suspended Sediments during a Dry Season and Their Consequences on Metal Transportation in a Coral Reef Lagoon Impacted by Mining Activities, New Caledonia
}

\author{
Jean-Michel Fernandez ${ }^{1, *}$, Jean-Dominique Meunier ${ }^{2}$, Sylvain Ouillon ${ }^{3}$, Benjamin Moreton ${ }^{1}$, \\ Pascal Douillet ${ }^{4}$ and Olivier Grauby ${ }^{5}$ \\ 1 Analytical and Environmetal Laboratory (AEL), \\ Institut de Recherche pour le Développement (IRD)-Nouméa, BP A5, \\ 98800 Nouméa, Nouvelle-Calédonie; bmoreton@ael-environnement.nc \\ 2 Aix Marseille University, Centre National de la Recherche Scientifique (CNRS), IRD, \\ Unité Mixte de Recherche CEREGE, 13545 Aix en Provence CEDEX 05, France; meunier@cerege.fr \\ 3 Unité Mixte de Recherche LEGOS, Université de Toulouse, IRD, Centre National d'Etudes Spatiales (CNES), \\ CNRS, Université Paul Sabatier (UPS), 14 avenue Edouard Belin, 31400 Toulouse, France; \\ sylvain.ouillon@legos.obs-mip.fr \\ 4 Mediterranean Institute of Oceanography (MIO), Unité Mixte de Recherche 110, IRD, CNRS/Institut \\ National des Sciences de l'Univers (INSU), Aix Marseille Université, Université de Toulon, \\ 13284 Marseille, France; pascal.douillet@ird.fr \\ 5 CINaM-CNRS-Aix-Marseille Université, Campus de Luminy Case 913, 13288 Marseille CEDEX 9, France; \\ grauby@cinam.univ-mrs.fr \\ * Correspondence: jmfernandez@ael-environnement.nc; Tel.: +687-76-84-30
}

Academic Editor: Roger A. Falconer

Received: 30 March 2017; Accepted: 8 May 2017; Published: 10 May 2017

\begin{abstract}
Coral reef lagoons of New Caledonia form the second longest barrier reef in the world. The island of New Caledonia is also one of the main producers of nickel (Ni) worldwide. Therefore, understanding the fate of metals in its lagoon waters generated from mining production is essential to improving the management of the mining activities and to preserve the ecosystems. In this paper, the vertical fluxes of suspended particulate matter (SPM) and metals were quantified in three bays during a dry season. The vertical particulate flux (on average $37.70 \pm 14.60 \mathrm{~g} \cdot \mathrm{m}^{2} \cdot \mathrm{d}^{-1}$ ) showed fractions rich in fine particles. In Boulari Bay (moderately impacted by the mining activities), fluxes were mostly influenced by winds and SPM loads. In the highly impacted bay of St Vincent and in the weakly impacted bay of Dumbéa, tide cycles clearly constrained the SPM and metal dynamics. Metals were associated with clay and iron minerals transported by rivers and lagoonal minerals, such as carbonates, and possibly neoformed clay as suggested by an unusually Ni-rich serpentine. Particle aggregation phenomena led to a reduction in the metal concentrations in the SPM, as identified by the decline in the metal distribution constants $\left(K_{d}\right)$.
\end{abstract}

Keywords: suspended sediment; sediment transport; lagoon; geochemistry; Ni mining; sediment trap; hydrodynamics; New Caledonia; dry season

\section{Introduction}

The mining industry in New Caledonia is one of the most important environmental concerns for the tropical island lagoonal ecosystem [1-9].

With about $85 \%$ endemism among terrestrial plants, 24 different species of mangroves among the 70 listed throughout the world, about 2800 species of molluscs and the second longest barrier reef in 
the world [10-15], New Caledonia's ecosystems and biodiversity are highly sensitive to anthropogenic activities (e.g., [16-23] for its lagoons). Since the beginning of mining in New Caledonia, more than $160 \times 10^{6}$ tonnes of ore have been extracted. This has led to the mobilization and transport of approximately 300 million $\mathrm{m}^{3}$ of soil material (laterites). Opencast $\mathrm{Ni}$ mines have enhanced soil erosion and transportation of sediments and metals into the lagoon [19,24-27] with several consequences on the lagoonal ecosystems, including increased sedimentation rates; decreased light penetration and dissolved oxygen levels; and an increased metal contamination in the food web which may affect humans $[23,28,29]$. The Ni mining industry has flourished for over 25 years, and New Caledonia will remain one of the major worldwide Ni producers for the foreseeable future, with global Ni reserves estimated at around 20-25\% [30]. As a consequence, environmental studies are required in order to mitigate the effects of $400-500 \mathrm{~km}^{2}$ of deforestation specifically related to the mining industry in New Caledonia.

Numerous studies of the south-western lagoon of New Caledonia have been conducted investigating hydrodynamics, sediment transport, sedimentation dynamics, metal fluxes, accumulation zones, and particle sources [23,27,31-37]. In complement to these works, this paper aims at characterizing the suspended sediment mineralogy and geochemistry (including metals) in three bays; analysing the relationships between their composition and the mining activities; determining how hydrodynamics forced by wind regimes affect the transportation of particulate metals bounded to the lateritic Suspended Particulate Matter (SPM) into the lagoon. Three contrasting bays in the south west lagoon, where hydrodynamics modelling has been carried out [38-40] were selected: Boulari Bay, Dumbéa Bay and Saint Vincent Bay. Samples were collected during a dry season in order to limit the influence of riverine inputs which could affect the understanding of hydrodynamic regimes, during distinct wind regimes (trade wind and west-breezes) and two neap/spring tide cycles.

\section{Study Area}

New Caledonia is located at the southern end of the Melanesian Arc, near the Tropic of Capricorn. In New Caledonia, mining activities are almost exclusively conducted on the main island $\left(16,642 \mathrm{~km}^{2},[41]\right)$. In its south-western part, host rocks are composed of peridotites and harzburgites incorporating metals like $\mathrm{Ni}, \mathrm{Co}, \mathrm{Cr}, \mathrm{Fe}$ and $\mathrm{Mn}[42,43]$ in $\mathrm{Mg}$ and Fe-minerals. Elements like $\mathrm{Pb}$ and $\mathrm{Zn}$ are only present in significant quantities in rocks from the northernmost part of the island [44-49]. The weathering of peridotites results in the accumulation of transition metals in the saprolite (also called "garnierite") and the yellow lateritic layers which are subjected to mining extraction. On the top of the series, the red lateritic layer corresponds to a more advanced weathering state of the peridotites where the structure of the bedrock is no longer visible [50]. Mg and Si are very low and the main constituents are ferric hydroxides more or less widely crystallized in goethite. In the upper part of the profile, the ultimate term of the weathering process is represented by a ferricrete composed mostly of goethite and, in lower proportions, hematite.

The climate of New-Caledonia is dry-tropical [51] with alternating dry and wet seasons. South-East trade winds blow from October to May with a mean speed of $8 \mathrm{~m} \cdot \mathrm{s}^{-1}$ and from April to September a variable northern wind blows. The temperatures vary moderately between dry and wet seasons.

In the south-west lagoon of New Caledonia, the tide is mixed and mainly semi diurnal [38]. Due to the interaction between the different components, spring tide and neap tide periods alternate during a lunar month. The maximum tidal amplitude is $1.5 \mathrm{~m}$ during a spring tide.

Similar to most of the New Caledonian Rivers, the Coulée, Dumbéa and Tontouta Rivers have steep upper courses and much flatter lower courses where deposits of weathered bedrock products accumulate (Figure 1). Due to the tropical climate conditions in New Caledonia, the hydrological regime is of torrential type. During the dry season, sediment loads carried by the rivers are low because of the low energy for erosion and the weak transport capacity [52,53]. Rain events reaching $700 \mathrm{~mm}$ and more over a 24 -h period lead to intense weathering of the slopes and flushing of large quantities 
of suspended matter to the lagoon. Baltzer and Trescases [52] reported that during cyclone Brenda in 1968, over 20,000 t of particles were discharged in a single day through the Dumbéa River estuary. The present study focuses on the three above-mentioned estuaries located on the south-west coast of New Caledonia influenced by their respective watersheds (Figure 1).

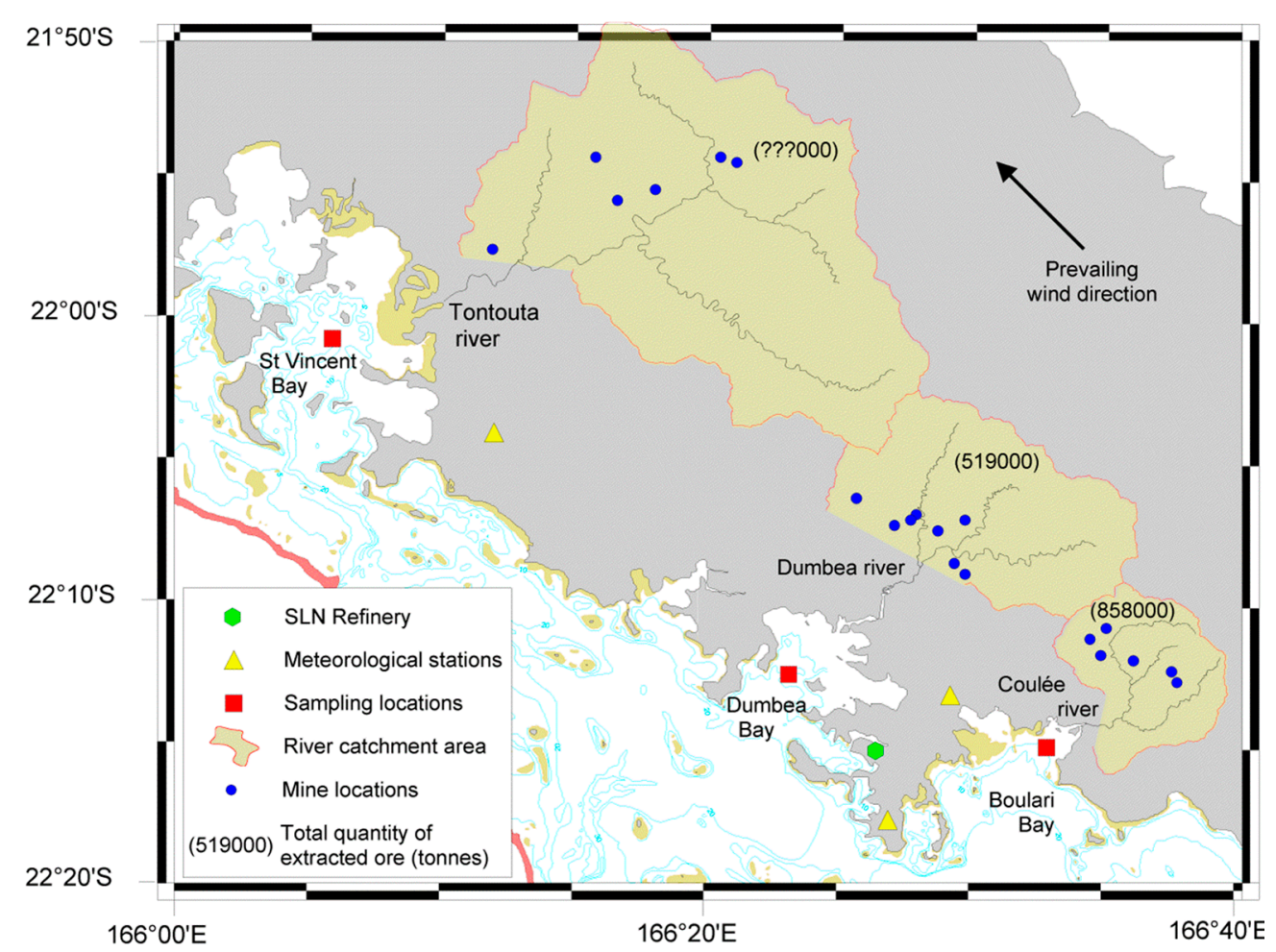

Figure 1. Map location of the study area in the west coast of New-Caledonia: Boulari Bay, influenced by a medium-scale mine activities until 1981; Dumbéa Bay, halted mining activity in order to maintain the water supply of Nouméa (the peninsula between Dumbéa Bay and Boulari Bay); St Vincent Bay, affected by intense opencast mining activities.

\subsection{Boulari Bay}

The Coulée River catchment $\left(92 \mathrm{~km}^{2}\right)$ is located almost entirely in the ultrabasic Grand Massif of the South New-Caledonia. An intermediate-scale mining operation was active in the area until 1981, but erosion from the initial prospecting and extraction sites has continued. The present terrigenous inputs delivered to Boulari Bay by the Coulée River result from combined natural and anthropogenic influences $[19,25]$. The river is extending its delta into the southern part of Boulari Bay where tidal mudflats are being formed.

\subsection{Dumbéa Bay}

The catchment area of Dumbéa River covers about $233 \mathrm{~km}^{2}$ and only a few small-scale localized garnierite extractions have occurred in the headwater regions. Similar to other drainage basins near the main city, Nouméa, any mining activities in the area have been forbidden since 1927 to maintain a quality water supply for the city. The sediment load yielded at the river mouth - where a mangrove extends - and delivered to Dumbéa Bay consists of clay, silts and sand, and the effects of mining activities have been limited $[25,26]$. 


\subsection{St Vincent Bay}

The Tontouta River and its tributaries form the largest of the three river catchments $\left(476 \mathrm{~km}^{2}\right)$ and drain a peridotic hinterland where opencast mining is still intense today. These activities extend to the mountain crests, and on hillslopes, only a few kilometres from the coast. The Tontouta River carries substantial amounts of fine terrigenous material that has resulted in a shallowing of the Saint Vincent Bay, particularly nearshore. The impact of mining activities appears to be stronger than in the Coulée catchment because of the lack of conservation work along the river and tributaries between 1960s and 1980s. This has led to a drastic increase in the sediment load at the river mouth.

\section{Materials and Methods}

During the dry season between 21 November and 14 December, 2005, SPM was sampled in the three bays every two days, and currents were measured continuously (Figure 1, Table 1). Rainfall rates, and wind direction and velocity were obtained from Météo-France's meteorological stations at Magenta airport, Mont Coffin and Tontouta airport close to Boulari Bay, Dumbéa Bay and Saint Vincent Bay, respectively.

Table 1. Sampling sites, depth and localisation.

\begin{tabular}{cccc}
\hline Site & Longitude & Latitude & Depth (m) \\
\hline Boulari Bay & E $166^{\circ} 32.126$ & S $22^{\circ} 15.355$ & 13.2 \\
Dumbéa Bay & E $166^{\circ} 23.243$ & S $22^{\circ} 12.291$ & 13.0 \\
St Vincent Bay & E $166^{\circ} 06.635$ & S $22^{\circ} 00.561$ & 12.8 \\
\hline
\end{tabular}

\subsection{SPM Sampling}

Three sequential sediment traps (model PPS 4/3; section of $0.05 \mathrm{~m}^{2}$, Technicap, La Turbie, France) were used for suspended particulate matter (SPM) sampling. They were moored at sites of $\sim 13 \mathrm{~m}$ depth downstream of the mouth of the Coulée, Dumbéa and Tontouta Rivers (Figure 1, Table 1). Samples were collected at a frequency of $48 \mathrm{~h}, 3 \mathrm{~m}$ above the seabed. The sediment traps were equipped with twelve $250 \mathrm{~mL}$ polypropylene vials filled with $5 \%$ formaldehyde-filtered seawater solution before mooring in order to preserve the particles from microbiological activity [54]. After sampling, the samples were placed in a refrigerator at $2-4{ }^{\circ} \mathrm{C}$ before analysis. Particles fluxes were calculated using the formula:

$$
\text { Flux }\left(\mathrm{g} \cdot \mathrm{m}^{-2} \cdot \mathrm{d}^{-1}\right)=\text { sample load }(\mathrm{g}) /\left(\text { Section area }\left(\mathrm{m}^{2}\right) * \text { Collecting time }(\mathrm{d}) \text { per flask }\right)
$$

\subsection{Current Measurement}

Currents were measured using an Acoustic Doppler Current Profilers (RDI Workhorse Monitor ADCP, Teledyne RD Instruments, Poway, USA 300 kHz, 12 cells, 1-m resolution) placed on the seabed in Dumbéa and St Vincent Bays (Figure 1). In Boulari Bay, local currents were measured using an Acoustic Doppler Velocimeter (Sontek) located $3 \mathrm{~m}$ above the seabed. Moored in the vicinity of the 3 sediment traps, the three current meters simultaneously recorded measurements during the SPM sampling period (one month). Unfortunately, due to technical problems, measurements are not available for Dumbéa Bay during the last ten days of the field campaign.

\subsection{In Situ Laser Grain Size and CTD Profiling}

Turbidity was measured regularly at each station by the use of a Seapoint Optical Backscattering Sensor (Seapoint Sensors, Inc., Brentwood, NH, USA) $(\lambda=880 \mathrm{~nm})$ connected to a Seabird SBE19 CTD profiler. The Seapoint sensor was factory-adjusted for a consistent response to Formazin Turbidity Standard measured in Formazin Turbidity Units (FTU). A former calibration showed that, in the 
south-west lagoon of New Caledonia, turbidity is related to the mass concentration (C) of SPM following [55]:

$$
\text { Turbidity }(\mathrm{FTU})=1.85 \mathrm{C}\left(\mathrm{mg} \cdot \mathrm{L}^{-1}\right)
$$

An in situ Laser Scattering and Transmissometry device (LISST-100X; Sequoia Scientific Inc., Bellevue, WA, USA) was used in situ to quantify the SPM and the Particle Size Distribution (PSD). The LISST-100X provides the distribution of particle volume concentrations in 32 size classes logarithmically spaced within the range 1.25-250 $\mu \mathrm{m}$ (e.g., [56]). Jouon et al. [55] gave an extended presentation of its first application in the lagoon of New Caledonia.

Synthetic parameters were defined to characterize the particle distribution: (1) the median diameter $\left(\mathrm{D}_{50}\right)$ as the diameter of a particle for which the cumulative volumetric distribution reaches $50 \%$ of the SPM volume concentration; (2) the Junge parameter (s) characterizing the slope of the particle size distribution (PSD) (e.g., [57,58]): high values correspond to SPM dominated by fine particles or aggregates, while low values correspond to macro-flocs; (3) the percentage of particles with diameter $>60 \mu \mathrm{m}$ that was shown to be an indicator of the state of aggregation [55].

\subsection{Geochemistry}

All apparatus was acid soaked (10\% nitric acid) for a minimum of five days and rinsed with ultrapure water (Milli-Q), and then stored in acid cleaned plastic bags until needed. While analytical acid grades were used for all cleaning steps, high purity reagents were used for all parts of the analytical procedure.

Seawater samples: Seawater was collected from the three bays using $5 \mathrm{~L}$ teflon lined Go-Flo ${ }^{\mathrm{TM}}$ water samplers (General Oceanics Inc., Miami, FL, USA). The Go-Flo ${ }^{\mathrm{TM}}$ water samplers were primed to be open at the site and lowered into the water, rinsed thoroughly and closed using a teflon-coated messenger. Once at the surface, samples were transferred in situ into acid cleaned HDPE bottles and sealed in clean plastic bags. After an on-line filtration at $0.45 \mu \mathrm{m}$ (Millipore acetate filters, Merck Millipore, Billerica, MA, USA), samples were then preconcentrated and analysed using ICP-OES following the procedure described by Moreton et al. [35]. Only the results for $\mathrm{Fe}, \mathrm{Mn}$ and $\mathrm{Ni}$, which represent the main elements used to trace watershed lixiviation, are presented in this article.

The accuracy and precision of the analytical results was controlled by assaying a SLEW-3 certified water sample (National Research Council, Canada), to check the preconcentration method. The stability of the ICP-OES was controlled inserting independent standards in the sample series: in our case, one at the beginning and one at the end. The quantification limits (LQ) of the method for the 3 metals, obtained after deduction of blanks, are given in Table 2.

Table 2. Results of the analysis of the reference material SLEW-3 and LQ of the method.

\begin{tabular}{cccc}
\hline \multirow{2}{*}{ Metal } & \multicolumn{2}{c}{ Reference Material SLEW-3 $\left(\mu \mathrm{g} \cdot \mathbf{L}^{-\mathbf{1}}\right)$} & \multirow{2}{*}{$\mathbf{L Q}\left(\boldsymbol{\mu g} \cdot \mathbf{L}^{\mathbf{- 1}}\right)$} \\
\cline { 2 - 3 } & Analysed $(\boldsymbol{n}=\mathbf{1})$ & Certified & \\
\hline $\mathrm{Fe}$ & 0.32 & $0.57 \pm 0.06$ & 0.068 \\
$\mathrm{Mn}$ & 1.92 & $1.61 \pm 0.22$ & 0.028 \\
$\mathrm{Ni}$ & 1.17 & $1.23 \pm 0.07$ & 0.022 \\
\hline
\end{tabular}

Particulate samples: Swimmers were removed from SPM collected at each site with sediment traps by sieving at $40 \mu \mathrm{m}$. The formaldehyde solution and salt were removed by rinsing several times and centrifuging. Organic matter and faecal pellets were destroyed using a solution of $30 \%$ hydrogen peroxide. The purified sediments were then oven dried at $60^{\circ} \mathrm{C}$ for a period of $72 \mathrm{~h}$.

Particulate metals were then dissolved by an alkaline fusion digestion performed using $0.5 \mathrm{~g}$ of lithium tetraborate mixed with $100 \mathrm{mg}$ of SPM and heated in a muffle furnace $\left(1100{ }^{\circ} \mathrm{C}\right)$ for $15 \mathrm{~min}$. The resulting amalgam was dissolved into $0.5 \mathrm{M} \mathrm{HCl}$, and the metals analysed. 
Analysis of 9 elements (Al, $\mathrm{Ca}, \mathrm{Co}, \mathrm{Cr}, \mathrm{Fe}, \mathrm{Mg}, \mathrm{Mn}, \mathrm{Ni}$ and $\mathrm{Si}$ ) in SPM was performed using an inductively coupled plasma optical emission spectrometer (Vista, Varian, Inc., Palo Alto, CA, USA).

The validity of the analysis was verified by assaying a MESS-3 certified sediment sample (National Research Council, Canada). The quantification limits (LQ) of the method for the 9 metals, obtained after deduction of blanks, are given in Table 3.

Table 3. Results of the analysis of the reference material MESS-3. The Quantification Limits of the method were not estimated because of the high levels of concentrations measured in SPM.

\begin{tabular}{|c|c|c|}
\hline \multicolumn{3}{|c|}{ Reference Material MESS-3 $\left(\mathrm{mg} \cdot \mathrm{kg}^{-1} \cdot \mathrm{dw}\right)$} \\
\hline Metal & Analyzed & Certified \\
\hline Al & 90,053 & $85,900 \pm 2300$ \\
\hline $\mathrm{Ca}$ & 13,746 & $14,700 \pm 600$ \\
\hline Co & 15.2 & $14.4 \pm 2.0$ \\
\hline $\mathrm{Cr}$ & 97 & $105 \pm 4$ \\
\hline Fe & 37,815 & $32,400 \pm 1200$ \\
\hline $\mathrm{Mg}$ & 16,905 & 16 \\
\hline Mn & 308 & $324 \pm 12$ \\
\hline $\mathrm{Ni}$ & 40.6 & $46.9 \pm 2.2$ \\
\hline Si & 232,765 & $270,000 *$ \\
\hline
\end{tabular}

Note: * Information value only.

\subsection{Kd Calculation}

Trace metal mobility in the lagoon water column was quantified through its distribution coefficient $\left(K_{d}\right.$, in $\left.\mathrm{mL} \cdot \mathrm{g}^{-1}\right)$, given by the following general formula:

$$
K_{d}=\frac{C_{p}}{C_{w}}
$$

with $C_{p}=$ metal concentration in SPM, $C_{w}=$ dissolved metal concentration in sea water.

\subsection{Mineralogy}

The mineralogical composition of the suspended sediments was determined using X-ray diffractometry (XRD), and Transmission Electron Microscopy (TEM). XRD analyses were done on slightly ground samples using Philips (PW1050/81) equipment (Philips, Eindhoven, The Netherlands) with a $\mathrm{Cu}$ anticathode. TEM observations were carried out on a JEOL-2000 FX microscope (JEOL USA, Inc., Peabody, MA, USA), operating with a beam intensity of $126 \mathrm{~mA}$ and an accelerating voltage of $200 \mathrm{kV}$. Microanalyses were acquired with a $\mathrm{Si}(\mathrm{Li})$ detector filled with a UTW and a Brucker Esprit EDS System. Quantitative data were obtained by the method developed by Cliff and Lorimer [59] after calibration of the $\mathrm{k}_{\mathrm{x}, \mathrm{Si}}$ factors $(\mathrm{x}=\mathrm{Al}, \mathrm{Mg} \ldots$ ) against natural and synthetic layer silicates of known and homogeneous composition.

\section{Results}

\subsection{Rainfall}

During the study period (21 November to 14 December 2005), rainfall was low, scarce and irregular over all 3 sites. Only one day of significant rainfall (12 December) was recorded at the meteorological stations at Magenta airport $(18 \mathrm{~mm})$ and Mont Coffin $(10 \mathrm{~mm})$. At the Tontouta airport station, the maximum rainfall was $6 \mathrm{~mm}$ on 9 December. Besides this, only $2 \mathrm{~mm}$ were recorded at the 3 stations on the 20 and 21 November and on 26 November. Generally, rainfall at the Tontouta station was systematically lower than at the two other stations. 


\subsection{Wind}

The meteorological stations at Magenta airport (near Boulari Bay) and Mont Coffin (between Dumbéa Bay and Boulari Bay, but representative of Dumbéa Bay conditions) recorded mainly two distinct regimes (Figure 2):

- A typical dominant trade wind regime during the study period, with the direction changing from NE during the night to SE in the day, increasing in strength until the beginning of the afternoon and reaching a maximum of $10 \mathrm{~m} \cdot \mathrm{s}^{-1}$ (periods B, D);

- A regime characterized by variable and weaker winds (below $5 \mathrm{~m} \cdot \mathrm{s}^{-1}$ ) (periods $\mathrm{A}, \mathrm{C}$ and $\mathrm{E}$ ).

The meteorological station at Tontouta airport (St Vincent Bay) recorded winds that were systematically weaker than those recorded at Magenta airport (Boulari Bay) and Mont Coffin (Dumbéa Bay). In the Saint Vincent Bay, wind speeds were lower than $6 \mathrm{~m} \cdot \mathrm{s}^{-1}$ and wind direction was irregular. In this area, trade winds are weakened by relief and coastal thermal breezes.

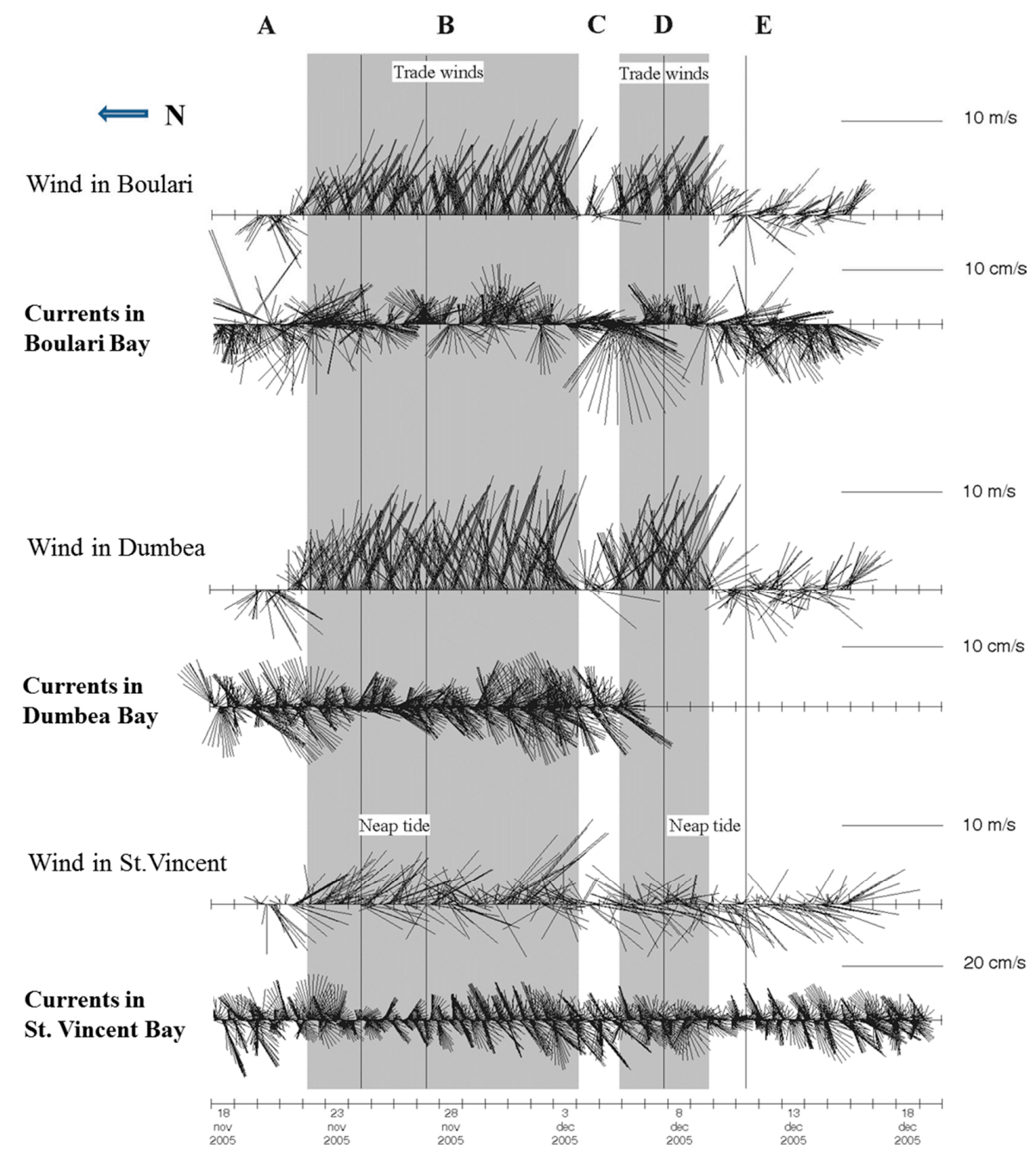

Figure 2. Wind and current speeds and directions for Boulari, Dumbéa and St Vincent bays during the study period (21 November to 14 December 2005).

\subsection{Hydrodynamics}

During the study period, the amplitudes of the semi-diurnal tides changed from 0.6 to $1.2 \mathrm{~m}$. Neap tide periods are identified in Figures 2 and 3. 

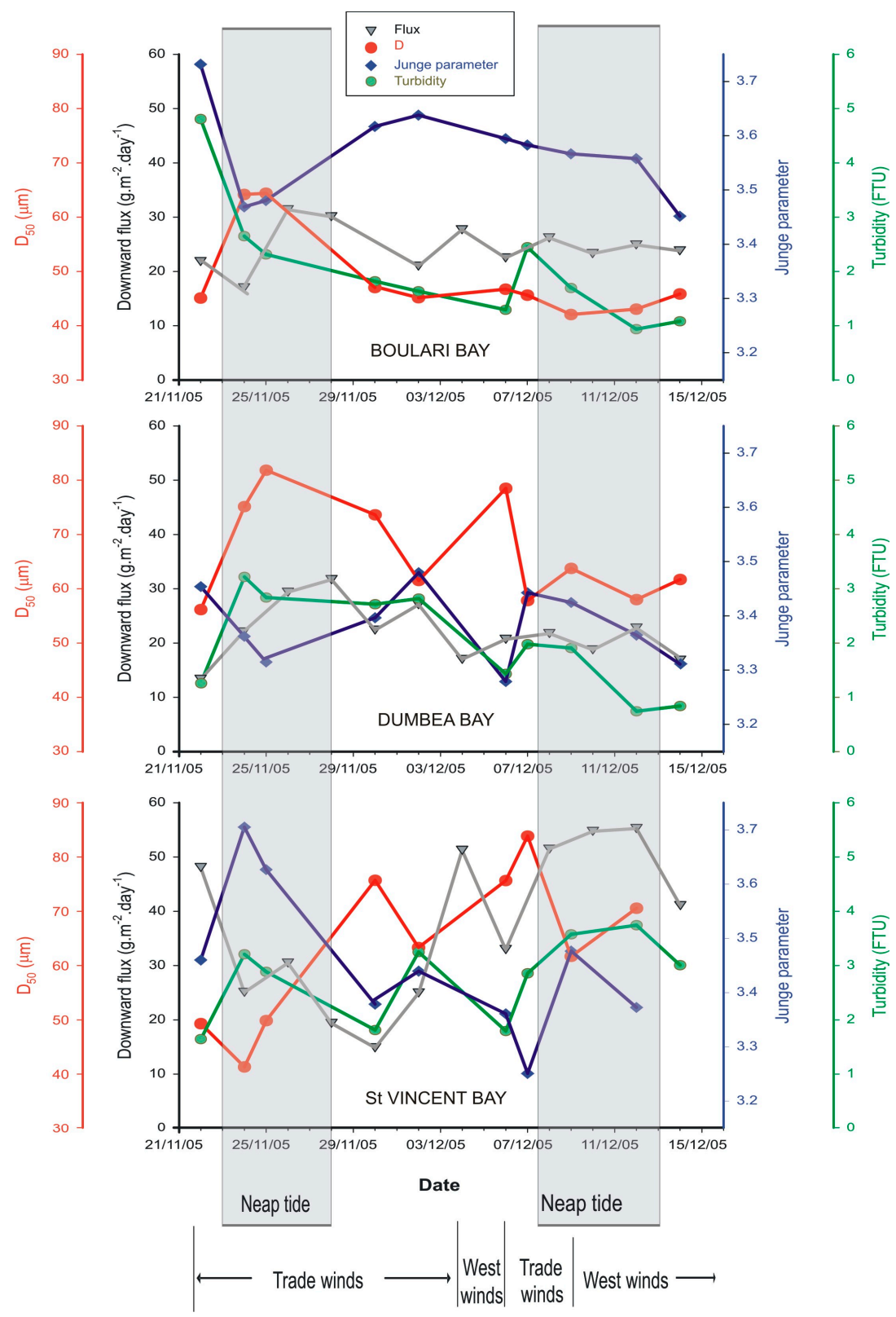

Figure 3. Median diameter (D50), Junge parameter (s), flux and turbidity for Boulari, Dumbéa and St Vincent bays over the study period (21 November to 14 December 2005), $3 \mathrm{~m}$ above the seabed.

In Boulari Bay, the neap/spring tide cycles had a non-significant influence on the currents measured $3 \mathrm{~m}$ above the seabed (Figure 2). In the absence of trade winds (periods $\mathrm{C}$ and $\mathrm{E}$ ), a strong westward flow was observed during several days and may indicate the development of a cyclonic gyre circulation along the isobaths from Mont-Dore (SW of Boulari Bay) towards Nouméa (as described by Fernandez et al. [27]). This gyre results from the conjunction of the propagation of the tide along the coastline of the bay. During trade winds (periods B and D), which blew from an E-NE direction in the Coulée River valley in the morning and from the SE in the afternoon, an anticyclonic gyre generated flows toward the East (as described by Douillet et al. [39]). However, during short periods (28 and 30 November and 2 December), flows in the opposite direction were observed. The present data suggest the strong impact of winds on currents in Boulari Bay, and the formation of a drive out phenomena of waters which were accumulated at the bottom of the bay only when trade winds blow. 
In Dumbéa Bay, the strong tidal influence and the weak effects of the wind on the direction and the strength of the currents $3 \mathrm{~m}$ above seabed were noticed: flows were the highest during spring tides and lowest during neap tides (Figure 2). Furthermore, currents were similar at the same periods of the tide but with different wind forcings, for example, during a neap tide, with low wind ( 20 and 21 November) and with a trade wind ( 3 and 4 December). This suggests that the wind has little influence on the water circulation in an area that is partly protected from the trade winds by the topography.

In St Vincent Bay, the strength of the currents $3 \mathrm{~m}$ above the seabed strongly depended on tide cycles (Figure 2); currents rotated 180 degrees during a neap-spring tide cycle, the currents being stronger during spring tides and lower during neap tides. The weakest flows were measured between 24 to 27 November and 24 to 27 December during neap tides. The strongest currents were recorded during spring tides around 3 December. Tides are thus the major factor influencing hydrodynamics in St Vincent Bay. A residual drift of the current to the S-W was observed; however, its value was low.

\subsection{SPM Collection}

In Boulari Bay, the SPM load collected over 48-h periods ranged between 1.72 and $3.16 \mathrm{~g}$, corresponding to downward fluxes in the range 17.23 to $31.63 \mathrm{~g} \cdot \mathrm{m}^{-2} \cdot \mathrm{d}^{-1}$ (Table 4 ), with an average value of $24.14 \mathrm{~g} \cdot \mathrm{m}^{-2} \cdot \mathrm{d}^{-1}\left(\sigma=4.50 \mathrm{~g} \cdot \mathrm{m}^{-2} \cdot \mathrm{d}^{-1}\right)$. The maximum fluxes were recorded over the period of 4 days from 25 to 28 November $\left(\mathrm{F}>30 \mathrm{~g} \cdot \mathrm{m}^{-2} \cdot \mathrm{d}^{-1}\right)$ and the minimum on 23 to 24 November and 29 to 30 November $\left(\mathrm{F} \approx 17 \mathrm{~g} \mathrm{~m}^{-2} \cdot \mathrm{d}^{-1}\right)$.

Table 4. Mass (g) of suspended particulate matter collected over $48 \mathrm{~h}$ in sediment traps in the three sampling bays during the study period (21 November to 14 December 2005).

\begin{tabular}{cccc}
\hline Date & Boulari Bay & Dumbéa Bay & St Vincent Bay \\
\hline 21-22 November & 2.21 & 1.29 & 4.83 \\
23-24 November & 1.72 & 2.16 & 2.53 \\
25-26 November & 3.16 & 2.84 & 3.07 \\
27-28 November & 3.03 & 3.19 & 1.96 \\
29-30 November & 1.74 & 2.26 & 1.51 \\
1-2 December & 2.12 & 2.78 & 2.52 \\
3-4 December & 2.79 & 1.95 & 5.15 \\
5-6 December & 2.27 & 2.09 & 3.32 \\
7-8 December & 2.64 & 2.20 & 5.17 \\
9-10 December & 2.35 & 1.90 & 5.50 \\
11-12 December & 2.51 & 2.30 & 5.55 \\
13-14 December & 2.40 & 1.71 & 4.12 \\
\hline
\end{tabular}

In Dumbéa Bay, the SPM load was similar to that of Boulari Bay with fluxes between 12.92 and $31.93 \mathrm{~g} \cdot \mathrm{m}^{-2} \cdot \mathrm{d}^{-1}$, and a mean value of $22.24 \mathrm{~g} \cdot \mathrm{m}^{-2} \cdot \mathrm{d}^{-1}\left(\sigma=5.20 \mathrm{~g} \cdot \mathrm{m}^{-2} \cdot \mathrm{d}^{-1}\right)$. The maximum fluxes were recorded over the period of 4 days from 25 to 28 November $\left(\mathrm{F} \approx 32 \mathrm{~g} \cdot \mathrm{m}^{-2} \cdot \mathrm{d}^{-1}\right)$ and the minimum on 22 November $\left(\mathrm{F} \approx 13 \mathrm{~g} \cdot \mathrm{m}^{-2} \cdot \mathrm{d}^{-1}\right)$.

The values in St Vincent Bay were clearly different with a higher average value of $37.70 \mathrm{~g} \cdot \mathrm{m}^{-2} \cdot \mathrm{d}^{-1}$ $\left(\sigma=14.60 \mathrm{~g} \cdot \mathrm{m}^{-2} \cdot \mathrm{d}^{-1}\right)$. Variations around the average value were large with frequent loads higher than $50 \mathrm{~g} \cdot \mathrm{m}^{-2} \cdot \mathrm{d}^{-1}$. Except on 21 and 22 November, the first half of the sampling period was characterised by low fluxes $\left(15<\mathrm{F}<31 \mathrm{~g} \cdot \mathrm{m}^{-2} \cdot \mathrm{d}^{-1}\right)$ and from 4 December onwards, the values were much higher $\left(33<\mathrm{F}<56 \mathrm{~g} \cdot \mathrm{m}^{-2} \cdot \mathrm{d}^{-1}\right)$.

For each bay, variations in the fluxes, turbidity, $\mathrm{D}_{50}$ (mean diameter of SPM from measurements in the range $1.25-250 \mu \mathrm{m}$ ) and Junge parameter (s) during the study period are presented in Figure 3.

\subsection{Turbidity, Water Column Structure, and Particle Dynamics}

Turbidity was systematically higher in the bay of St Vincent with an average value of 2.8 FTU, compared with average values around 2.0 FTU in the other two bays (Table 5). 
In Boulari Bay between 21 and 24 November, the median diameter $\left(D_{50}\right)$ increased from 45 to $64 \mu \mathrm{m}$ while the Junge parameter (s) decreased from 3.75 to 3.48 (Figure 3). While fine particles dominated initially, coarser and medium sizes suddenly increased (24 and 25 November) two days after the beginning of the trade-winds. After 25 November, the decrease of $\mathrm{D}_{50}$ was fairly constant up to the end of the study period, when the value reached $42 \mu \mathrm{m}$. Conversely, the Junge parameter increased until December $2(s=3.63)$, then decreased gradually up to 12 December and then increased sharply until December 14. The downward flux of particles increased just after the peak of coarser particles (26 November) and slightly decreased afterwards (Figure 3). Although generally ranging between 1 and 3 FTU, turbidity showed values around 7.5 FTU in the bottom first four metres above seabed, at the beginning of the study period. Another nepheloid layer, of weaker intensity (4.5 FTU), was also observed around 7 December. The particle grain size distribution was fairly homogeneous throughout the water column during the study period except on the 12 and 14 December when the concentration of fine particles $(<7.75 \mu \mathrm{m})$ increasing towards the seabed was observed.

Table 5. Main characteristics (mean temperature, salinity and turbidity) recorded in the three sites during the study period (21 November to 14 December, 2005).

\begin{tabular}{ccccc}
\hline Site & Statistics & Temperature $\left({ }^{\circ} \mathbf{C}\right)$ & Salinity (\%o) & Turbidity (FTU) \\
\hline \multirow{2}{*}{ Boulari Bay } & Mean \pm Std Dev. & $26.0 \pm 0.6$ & $35.9 \pm 0.3$ & $2.1 \pm 1.1$ \\
& Min.-Max. & $25.3-27.5$ & $35.4-36.9$ & $0.5-7.6$ \\
\hline \multirow{2}{*}{ Dumbéa Bay } & Mean \pm Std Dev. & $26.5 \pm 0.5$ & $36.1 \pm 0.1$ & $2.0 \pm 0.9$ \\
& Min.-Max. & $24.8-27.6$ & $35.3-36.6$ & $0.5-5.5$ \\
\hline \multirow{2}{*}{ St Vincent Bay } & Mean \pm Std Dev. & $26.9 \pm 1.0$ & $36.1 \pm 0.1$ & $2.8 \pm 0.8$ \\
& Min.-Max. & $25.3-28.8$ & $35.2-36.5$ & $1.4-7.8$ \\
\hline
\end{tabular}

In Dumbéa Bay, the evolution of the median diameter and the Junge parameter were almost inversely related (Figure 3): for example, the two maximum values of $D_{50}$ measured on 25 November $(82 \mu \mathrm{m})$ and 6 December $(79 \mu \mathrm{m})$ corresponded with the minimal values of $s(3.32$ and 3.28), respectively. Turbidity stayed fairly homogeneous throughout the water column, but decreased with time from 3.2 FTU to 0.8 FTU. Only two profiles (11 November and 12 December) showed a clear increase in turbidity towards the bottom. A general decrease in the volumetric concentration, detected between 24 November $\left(10 \mu \mathrm{L} \cdot \mathrm{L}^{-1}\right)$ and 14 December $\left(5 \mu \mathrm{L} \cdot \mathrm{L}^{-1}\right)$, combined with a decrease in turbidity, was caused by a reduction in the largest particle-size ranges $(\varnothing>40.6 \mu \mathrm{m})$. After 9 December, the reduction in the volumetric concentration was due to a decrease in both the smallest $(\varnothing<7.75 \mu \mathrm{m})$ and largest particle-size $(\varnothing>40.6 \mu \mathrm{m})$ populations. At the very end of the measurement period, an increase in the amount of fine particles $(\varnothing<7.75 \mu \mathrm{m})$ was observed at depth, with large particles $(\varnothing>40.6 \mu \mathrm{m})$ towards the surface.

In St Vincent Bay, the minimum median diameter $(42 \mu \mathrm{m})$ was measured at the beginning of the study period (24 November) (Figure 3). $\mathrm{D}_{50}$ increased gradually until 7 December $(85 \mu \mathrm{m})$ with an intermediate maximum value observed on 30 November $(76 \mu \mathrm{m})$. From the 9 to the 12 December, the median diameter increased from 62 to $70 \mu \mathrm{m}$. The Junge parameter followed an exact opposite evolution. The maximum value was 3.70 on 24 November and the minimal value was 3.25 on 7 December. From the 9 to the 12 December, the parameter $s$ decreased from 3.46 to 3.38. Turbidity ranged between 1.5 and 3.0 FTU in the first few metres below the surface. From 2 December until the end of the study period, turbidity systematically increased towards the seabed with a consistently higher total volumetric concentration. A significant population of particles above $40 \mu \mathrm{m}$ and high downward fluxes of particles were observed throughout the study period (Figure 3). High downward fluxes varied similar to turbidity after a short delay.

The values of the median diameter and the Junge parameter strongly differed from one bay to another (Figure 3). $D_{50}$ values ranged between 42 and $65 \mu \mathrm{m}$ in Boulari Bay (median $D_{50}=48.9 \mu \mathrm{m}$ ), between 55 and 82 in Dumbéa Bay (median $\mathrm{D}_{50}=66.8 \mu \mathrm{m}$ ) and between 42 and $84 \mu \mathrm{m}$ in St Vincent 
Bay (median $\mathrm{D}_{50}=63.4 \mu \mathrm{m}$ ). The Junge parameter $s$ values ranged between 3.45 and 3.73 in Boulari Bay (median $s=3.58$ ), 3.28 and 3.48 in Dumbéa Bay (median $s=3.38$ ) and 3.25 and 3.70 in St Vincent Bay (median $s=3.45$ ). The $s$ parameter variation was minimal in Dumbéa Bay and maximal in St Vincent Bay, the variation of $D_{50}$ was minimal in Boulari Bay and maximal in St Vincent Bay.

\subsection{Geochemistry}

The chemical composition of the seawaters in the 3 bays (Table 6) differed in their dissolved Fe, $\mathrm{Mn}$ and Ni concentration. The respective highest and the lowest concentrations were measured in St Vincent Bay and in Boulari Bay. Fe and especially Mn were found at much lower concentration than Ni.

These values are high but reflect the influence of the geology of New Caledonia on the concentrations in dissolved metals. The values show a typical "coast-to-offshore" gradient, with maximum concentrations in bays influenced by rivers and minimum near the coral reef-barrier (Table 7). This evolution is similar to that of the lateritic metals analysed in the sedimentary cover [27].

During the study, Mn concentrations were similar for the 3 bays, with limited variation between 0.33 to $1.24 \mu \mathrm{g} \cdot \mathrm{L}^{-1}$. The respective $\mathrm{Fe}$ and $\mathrm{Ni}$ ranges were larger, i.e., $0.23-2.65 \mu \mathrm{g} \cdot \mathrm{L}^{-1}$ and 0.95 to $7.10 \mu \mathrm{g} \cdot \mathrm{L}^{-1}$ in the 3 bays. Indeed, in Boulari Bay, the maximum Fe values were measured on 24 and 30 November, and were slightly higher on 8 December, and seemed to coincide with those of Ni. For the other two bays, the concentrations of theses metals changed differently over time. For example, for $\mathrm{Ni}$, maximum concentrations were measured on 24 November, 2 December and 22 November, for Boulari, Dumbéa and St Vincent bays, respectively.

Table 6. Concentration of the dissolved $\mathrm{Fe}, \mathrm{Mn}$ and $\mathrm{Ni}$ in seawater during the study period from 22 November to 14 December 2005 in the 3 bays.

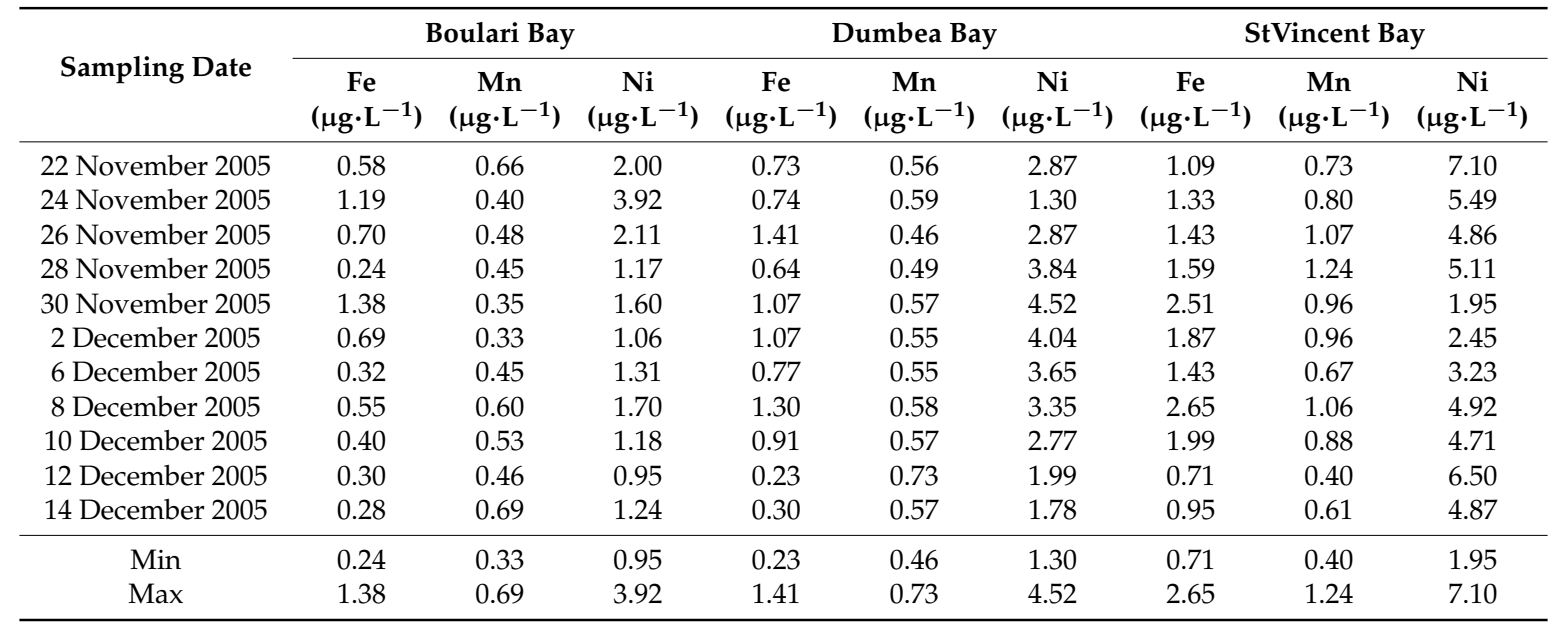

The analytical results showed that the SPM collected in St Vincent Bay had a distinctly different chemical composition to that of the other two bays (Table 8 and Figure 4). Indeed, in St Vincent Bay's SPM, 7 of the 9 analysed metals ( $\mathrm{Co}, \mathrm{Cr}, \mathrm{Fe}, \mathrm{Mg}, \mathrm{Mn}, \mathrm{Ni}, \mathrm{Si}$ ) were highly enriched, up to one order of magnitude (e.g., $\mathrm{Co}, \mathrm{Ni}$ or $\mathrm{Mn}$ ) compared with the two others sites. Only the behaviour of $\mathrm{Ca}$ differed, being slightly more concentrated in the SPM collected in Dumbéa Bay, particularly during the second half of the sampling period (Figure 4).

In terms of intra-site variability, the metal and Ca concentrations remained relatively constant in St Vincent Bay's SPM, while they evolved in Dumbéa Bay and particularly in Boulari Bay (Figure 4). This time-variation started with high metal concentrations at the beginning of the study period ( 21 and 22 November) followed by a strong decrease over a 4-day period ( 23 to 27 November) before increasing to the highest values at the end of the sampling period. This increasing trend was irregular in Dumbéa Bay, where the highest concentrations were observed from 4 December, while in Boulari 
Bay, the increase was slight but continuous to reach the maximum values for all the metals and Ca on 14 December. The mean concentrations increased about 2, 3 and 5 times, in St Vincent, Dumbéa and Boulari bays, respectively.

Table 7. Concentrations of dissolved $\mathrm{Fe}, \mathrm{Mn}$ and $\mathrm{Ni}$ in bays and coral reef barrier $(n=965)$. Analysis carried out between November 2013 and August 2016 in the frame of marine environmental monitoring along the west coast of New Caledonia (unpublished environmental monitoring data of the surrounding area of the KNS plant). Observed especially in the shallow bays, the extreme Std Deviations demonstrate the high variability of the metal concentration levels generated by the lixiviation of the exploited basins.

\begin{tabular}{cccc}
\hline Location & Fe $\left(\mu \mathrm{g} \cdot \mathbf{L}^{-\mathbf{1}}\right)$ & $\mathbf{M n}\left(\boldsymbol{\mu g} \cdot \mathbf{L}^{-\mathbf{1}}\right)$ & $\mathbf{N i}\left(\boldsymbol{\mu g} \cdot \mathbf{L}^{-\mathbf{1}}\right)$ \\
\hline Bays $(n=288)$ & $0.241 \pm 0.444$ & $4.565 \pm 9.802$ & $2.904 \pm 4.700$ \\
Intermediate $(n=315)$ & $0.123 \pm 0.095$ & $0.422 \pm 0.659$ & $0.322 \pm 0.423$ \\
Reef $(n=362)$ & $0.058 \pm 0.061$ & $0.103 \pm 0.095$ & $0.115 \pm 0.100$ \\
\hline
\end{tabular}



(a)

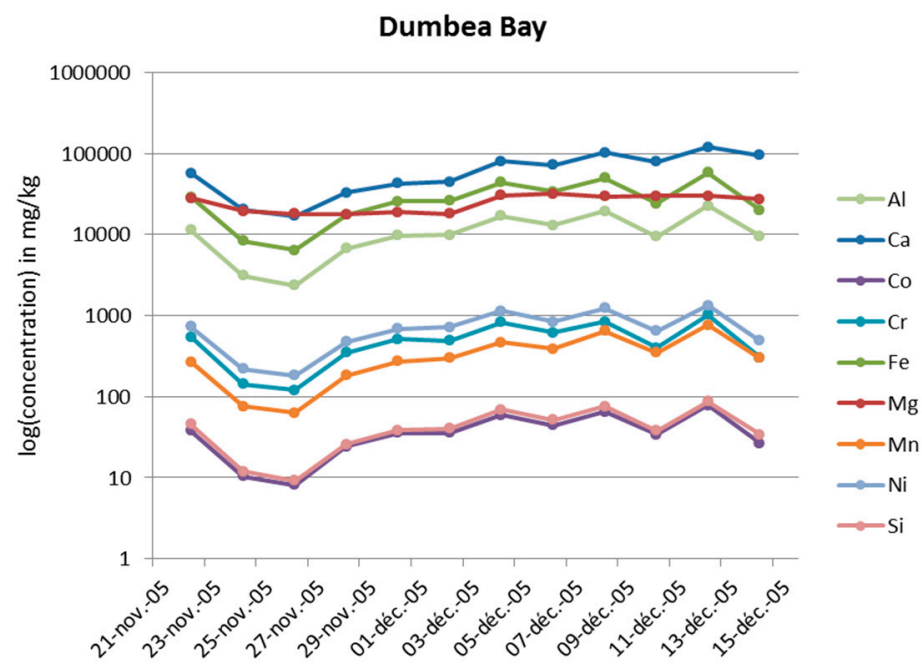

(b)

Figure 4. Cont. 


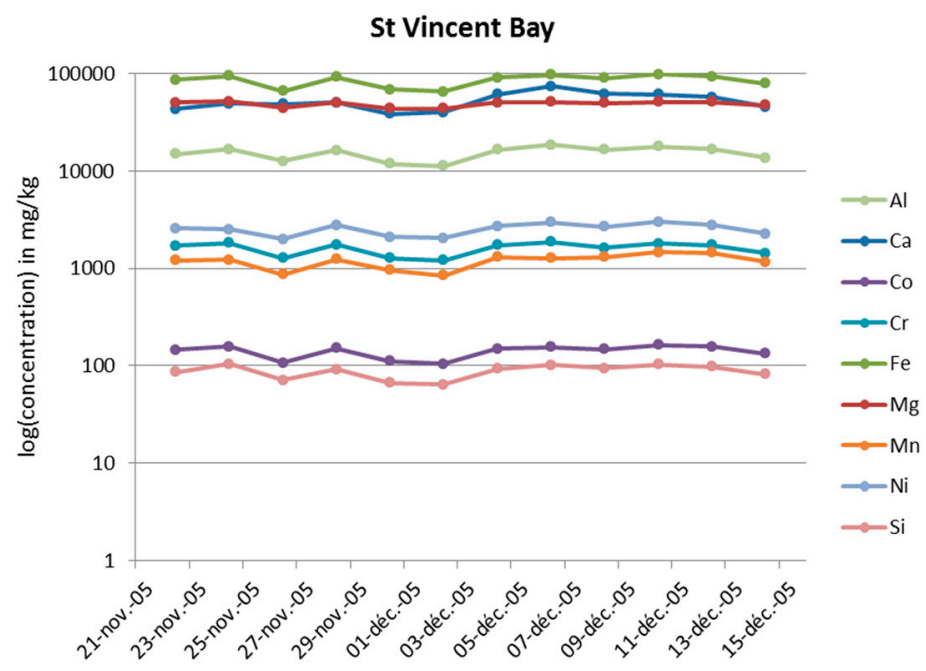

(c)

Figure 4. Time variation of the $\mathrm{Ca}$ and the 8 metals analysed in SPM trapped during study period from 21 November to 14 December, 2005 in each sampling site: (a) Boulari Bay; (b) Dumbéa Bay and (c) St Vincent Bay.

Table 8. Minimum and maximum concentrations for the analysed elements in SPM trapped during study period from 21 November to 14 December 2005 in each sampling site.

\begin{tabular}{ccccccccccc}
\hline \multicolumn{2}{l}{ Concentration (mg kg-1) } & Al & Ca & Co & Cr & Fe & Mg & Mn & Ni & Si \\
\hline \multirow{2}{*}{ Boulari bay } & Min & 1930 & 12,990 & 13 & 208 & 690 & 15,874 & 87 & 195 & 4750 \\
& Max & 11,520 & 53,710 & 76 & 1209 & 51,820 & 29,169 & 568 & 1157 & 31,850 \\
\hline \multirow{2}{*}{ Dumbéa bay } & Min & 6740 & 33,060 & 24 & 306 & 17,420 & 17,672 & 183 & 473 & 25,830 \\
& Max & 22,740 & 119,600 & 78 & 1025 & 58,190 & 32,064 & 765 & 1332 & 86,590 \\
\hline \multirow{2}{*}{ StVincent bay } & Min & 11,220 & 38,360 & 105 & 1204 & 64,670 & 43,684 & 844 & 2033 & 63,780 \\
& Max & 18,440 & 73,950 & 164 & 1856 & 97,900 & 51,051 & 1459 & 3012 & 102,940 \\
\hline
\end{tabular}

For each bay, variations in elements concentrations were remarkably correlated $\left(R^{2}>0.850\right)$ except for (Table 9): (i) Mg, where concentrations showed poor correlations with other SPM metals in Dumbéa Bay (mean $\mathrm{R}^{2} \approx 0.480$ ) and no correlation in Boulari Bay (mean $\mathrm{R}^{2} \approx 0.223$ ); (ii) Ca and all the other metals in St Vincent Bay (mean $\mathrm{R}^{2} \approx 0.534$ ), and, to a lesser extent, in Dumbéa Bay (mean $\mathrm{R}^{2} \approx 0.710$ ), and with $\mathrm{Mg}$ in Boulari Bay $\left(\mathrm{R}^{2}=0.236\right)$.

Table 9. Correlation coefficients $\left(\mathrm{R}^{2}\right)$ for $\mathrm{Ca}, \mathrm{Mg}, \mathrm{Fe}, \mathrm{Co}, \mathrm{Cr}, \mathrm{Mn}, \mathrm{Ni}, \mathrm{Al}$ and $\mathrm{Si}$ concentrations in the suspended matter trapped from 21 November to 14 December in each sampling site: (a) Boulari Bay, (b) Dumbéa Bay and (c) St Vincent Bay.

\begin{tabular}{cccccccccc}
\hline \multicolumn{7}{c}{ Boulari Bay } \\
\hline & Ca & Mg & Fe & Co & Cr & Mn & Ni & Al & Si \\
\hline Ca & 1 & 0.236 & $\mathbf{0 . 9 9 4}$ & $\mathbf{0 . 9 8 9}$ & $\mathbf{0 . 9 8 7}$ & $\mathbf{0 . 9 8 8}$ & $\mathbf{0 . 9 8 8}$ & $\mathbf{0 . 9 9 5}$ & $\mathbf{0 . 9 9 3}$ \\
$\mathbf{M g}$ & & 1 & 0.221 & 0.223 & 0.217 & 0.248 & 0.209 & 0.233 & 0.212 \\
Fe & & & 1 & $\mathbf{0 . 9 9 8}$ & $\mathbf{0 . 9 9 4}$ & $\mathbf{0 . 9 9 5}$ & $\mathbf{0 . 9 9 3}$ & $\mathbf{0 . 9 9 9}$ & $\mathbf{0 . 9 9 3}$ \\
$\mathrm{Co}$ & & & & 1 & $\mathbf{0 . 9 9 6}$ & $\mathbf{0 . 9 9 8}$ & $\mathbf{0 . 9 9 4}$ & $\mathbf{0 . 9 9 5}$ & $\mathbf{0 . 9 8 6}$ \\
$\mathrm{Cr}$ & & & & & 1 & $\mathbf{0 . 9 9 2}$ & $\mathbf{0 . 9 9 2}$ & $\mathbf{0 . 9 9 3}$ & $\mathbf{0 . 9 8 3}$ \\
$\mathrm{Mn}$ & & & & & & 1 & $\mathbf{0 . 9 9 1}$ & $\mathbf{0 . 9 9 4}$ & $\mathbf{0 . 9 8 4}$ \\
$\mathrm{Ni}$ & & & & & & & 1 & $\mathbf{0 . 9 9 1}$ & $\mathbf{0 . 9 8 2}$ \\
$\mathrm{Al}$ & & & & & & & & 1 & $\mathbf{0 . 9 9 6}$ \\
$\mathrm{Si}$ & & & & & & & & & 1 \\
\hline
\end{tabular}

(a) 
Table 9. Cont.

\begin{tabular}{cccccccccc}
\hline & \multicolumn{7}{c}{ Dumbéa Bay } \\
\hline & Ca & Mg & Fe & Co & Cr & Mn & Ni & Al & Si \\
\hline Ca & 1 & 0.688 & 0.702 & 0.701 & 0.604 & $\mathbf{0 . 8 2 6}$ & 0.655 & 0.772 & 0.734 \\
$\mathbf{M g}$ & & 1 & 0.484 & 0.468 & 0.419 & 0.497 & 0.461 & 0.514 & 0.516 \\
$\mathbf{F e}$ & & & 1 & $\mathbf{0 . 9 9 8}$ & $\mathbf{0 . 9 8 5}$ & $\mathbf{0 . 9 4 6}$ & $\mathbf{0 . 9 8 8}$ & $\mathbf{0 . 9 9 2}$ & $\mathbf{0 . 9 9 7}$ \\
$\mathrm{Co}$ & & & & 1 & $\mathbf{0 . 9 8 6}$ & $\mathbf{0 . 9 4 8}$ & $\mathbf{0 . 9 9 0}$ & $\mathbf{0 . 9 8 9}$ & $\mathbf{0 . 9 9 4}$ \\
$\mathrm{Cr}$ & & & & & 1 & $\mathbf{0 . 8 8 8}$ & $\mathbf{0 . 9 8 6}$ & $\mathbf{0 . 9 6 2}$ & $\mathbf{0 . 9 7 7}$ \\
$\mathbf{M n}$ & & & & & & 1 & $\mathbf{0 . 9 1 2}$ & $\mathbf{0 . 9 6 2}$ & $\mathbf{0 . 9 4 5}$ \\
$\mathrm{Ni}$ & & & & & & & 1 & $\mathbf{0 . 9 7 1}$ & $\mathbf{0 . 9 8 8}$ \\
$\mathrm{Al}$ & & & & & & & & 1 & $\mathbf{0 . 9 9 5}$ \\
$\mathrm{Si}$ & & & & & & & & & 1 \\
\hline
\end{tabular}

(b)

\begin{tabular}{cccccccccc}
\hline \multicolumn{7}{c}{ St Vincent Bay } \\
\hline & Ca & Mg & Fe & Co & Cr & Mn & Ni & Al & Si \\
\hline Ca & 1 & 0.438 & 0.542 & 0.448 & 0.483 & 0.450 & 0.634 & 0.725 & 0.552 \\
Mg & & 1 & $\mathbf{0 . 9 5 3}$ & $\mathbf{0 . 9 5 8}$ & $\mathbf{0 . 9 6 1}$ & $\mathbf{0 . 8 0 8}$ & $\mathbf{0 . 8 1 3}$ & $\mathbf{0 . 8 7 8}$ & $\mathbf{0 . 9 2 0}$ \\
Fe & & & 1 & $\mathbf{0 . 9 8 6}$ & $\mathbf{0 . 9 6 3}$ & $\mathbf{0 . 8 6 9}$ & $\mathbf{0 . 9 0 5}$ & $\mathbf{0 . 9 5 4}$ & $\mathbf{0 . 9 6 3}$ \\
Co & & & & 1 & $\mathbf{0 . 9 4 1}$ & $\mathbf{0 . 9 0 3}$ & $\mathbf{0 . 8 6 6}$ & $\mathbf{0 . 9 0 4}$ & $\mathbf{0 . 9 4 9}$ \\
Cr & & & & & 1 & $\mathbf{0 . 7 5 4}$ & $\mathbf{0 . 8 5 3}$ & $\mathbf{0 . 9 2 2}$ & $\mathbf{0 . 9 3 2}$ \\
$\mathbf{M n}$ & & & & & & 1 & $\mathbf{0 . 8 3 3}$ & $\mathbf{0 . 7 9 6}$ & $\mathbf{0 . 8 0 6}$ \\
Ni & & & & & & & 1 & $\mathbf{0 . 9 0 8}$ & $\mathbf{0 . 8 0 3}$ \\
Al & & & & & & & & 1 & $\mathbf{0 . 9 4 8}$ \\
Si & & & & & & & & & \\
\hline
\end{tabular}

(c)

The geochemical compositions of SPM (Figure 4, Table 8, which differed substantially between the 3 bays, contrast strongly with the average composition of red laterites (Table 10). Comparatively, red laterite showed much lower levels of $\mathrm{Ca}, \mathrm{Mg}$ and $\mathrm{Si}$ (Table 10), being composed principally of Fe with a high proportion of $\mathrm{Cr}$. The concentrations of the other elements in the red laterites were the same order of magnitude as those observed in the SPMs collected in the bays.

Table 10. Mean concentrations $(n=22)$ of the main elements analysed in the red laterite of the south and west coastal ore sites of New Caledonia.

\begin{tabular}{cccccccccc}
\hline Concentration $\left(\mathbf{m g} \cdot \mathbf{k g}^{\mathbf{- 1}}\right)$ & $\mathbf{A l}$ & $\mathbf{C a}$ & $\mathbf{C o}$ & $\mathbf{C r}$ & $\mathbf{F e}$ & $\mathbf{M g}$ & $\mathbf{M n}$ & $\mathbf{N i}$ & $\mathbf{S i}$ \\
\hline Mean & 26,566 & 117 & 437 & 19,677 & 586,760 & 2560 & 3887 & 5760 & 6920 \\
StDev & 3170 & 69 & 21 & 1309 & 46,928 & 381 & 221 & 939 & 1803 \\
\hline
\end{tabular}

\subsection{Mineralogy}

The minerals detected in both fractions $\varnothing<40 \mu \mathrm{m}$ and $\varnothing>40 \mu \mathrm{m}$ were not significantly different between each sampled site; the main difference being that clay minerals were enhanced in the finer fraction. The main minerals detected in the suspended sediments of the 3 bays analysed were: carbonates (calcite, Mg-calcite and aragonite), goethite, talc, serpentine and quartz (Figure 5). Smectite was detected in St Vincent and Boulari Bays, but was not significant in Dumbéa Bay. The peaks of talc and serpentine were less intense in Dumbéa Bay than in the two other bays. In the 3 sites, other detected, but less abundant, minerals were: kaolinite, feldspar, pyroxene, and olivine.

TEM observations were mainly focused on the Ni-bearing minerals found in the bays. Carbonates, quartz, feldspar, biogenic silica (diatom tests) detected by TEM did not contain $\mathrm{Ni}$, according to EDS spectra. Ni was detected in goethite and clay minerals (Figure 6 and Table 11). 


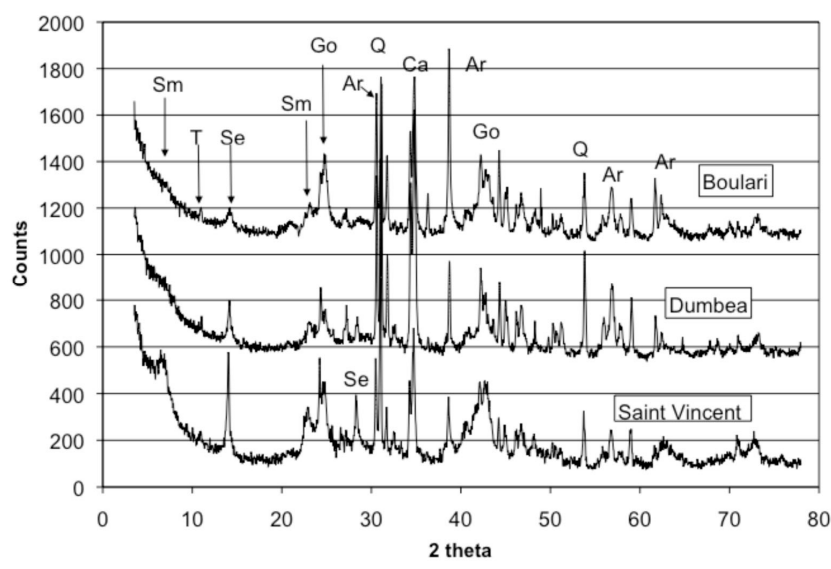

Figure 5. X-ray diffractograms of suspended particulate matter showing the main minerals found in the three study sites $(\mathrm{Sm}=$ smectite; $\mathrm{T}$ = talc; $\mathrm{Se}=$ serpentine; $\mathrm{Go}=$ goethite; $\mathrm{Ar}=$ aragonite; $\mathrm{Q}=$ quartz; $\mathrm{Ca}=$ Calcite).
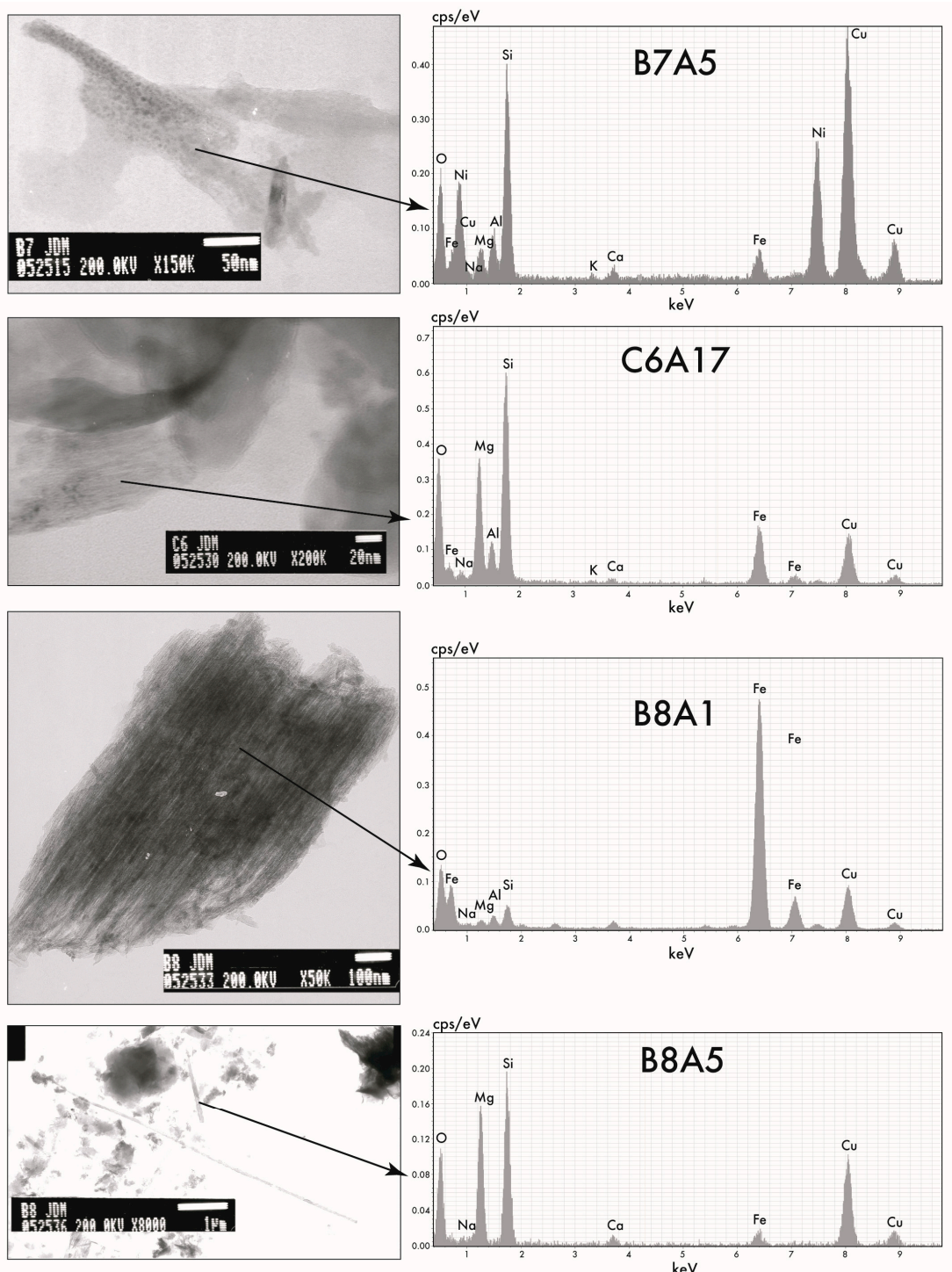

Figure 6. Images and composition determined by transmitted electron microscopy of some particles collected during the study. The chemical formulae are given in Table 11. 
Table 11. Chemical formulas of particles (from Figure 6) collected with sequential sediment traps compared to minerals reported in the literature: B7(A5) from St Vincent Bay collected on 12 December 2005; B8(A1) and B8(A5) collected from St Vincent Bay on 6 December, 2005 and C6(A17) collected from Dumbéa Bay on 2 December 2005.

\begin{tabular}{|c|c|c|c|c|c|c|c|c|c|c|}
\hline Sample & $\mathrm{SiO}_{2}(\%)$ & $\mathrm{Al}_{2} \mathrm{O}_{3}$ & $\mathrm{Fe}_{2} \mathrm{O}_{3}$ & $\mathrm{MgO}$ & $\mathrm{Cr}_{2} \mathrm{O}_{3}$ & $\mathrm{TiO}_{2}$ & $\mathrm{CaO}$ & $\mathrm{Na}_{2} \mathrm{O}$ & $\mathrm{K}_{2} \mathrm{O}$ & $\mathrm{NiO}$ \\
\hline $\mathrm{B} 7(A 5)$ & 42.22 & 7.11 & 6.93 & 4.82 & 0.21 & 0.00 & 1.77 & 0.17 & 0.44 & 36.33 \\
\hline $\mathrm{B} 8(A 1)$ & 5.77 & 1.95 & 86.84 & 0.58 & 0.98 & 0.00 & 1.75 & 0.00 & 0.00 & 2.14 \\
\hline B8(A5) & 51.58 & 0.12 & 4.95 & 39.31 & 0.29 & 0.00 & 2.33 & 0.42 & 0.25 & 0.7 \\
\hline $\mathrm{C} 6(A 17)$ & 48.57 & 7.4 & 16.11 & 25.49 & 0.49 & 0.00 & 0.84 & 0.13 & 0.26 & 0.72 \\
\hline Goethite* & 4.86 & 3.62 & 88.53 & 1.69 & 0.47 & 0.00 & 0.00 & 0.00 & 0.00 & 0.83 \\
\hline Lizardite ${ }^{* *}$ & 42.20 & 0.15 & 2.57 & 35.00 & 0.00 & 0.00 & 0.00 & 0.00 & 0.00 & 4.50 \\
\hline Antigorite* & 49.84 & 0.26 & 2.04 & 46.65 & 0.64 & 0.00 & 0.13 & 0.00 & 0.00 & 0.45 \\
\hline Talc* & 66.39 & 0.00 & 0.00 & 32.98 & 0.00 & 0.00 & 0.63 & 0.00 & 0.00 & 0.00 \\
\hline CryptoNont * & 51.58 & 8.42 & 24.21 & 12.63 & 0.00 & 0.00 & 0.00 & 0.00 & 0.00 & 3.16 \\
\hline CryptoSapo * & 50.53 & 10.53 & 13.68 & 25.26 & 0.00 & 0.00 & 0.00 & 0.00 & 0.00 & 0.00 \\
\hline Nontronite * & 55.67 & 4.26 & 33.02 & 3.65 & 0.23 & 0.00 & 0.26 & 0.00 & 0.00 & 2.91 \\
\hline Smectite * & 55.59 & 3.87 & 33.96 & 6.58 & 0.00 & 0.00 & 0.00 & 0.00 & 0.00 & 0.00 \\
\hline
\end{tabular}

Notes: * Trescases [50]; ${ }^{* *}$ Manceau et Calas [60]; $0.00=$ below detection limit or undetermined.

\section{Discussion}

\subsection{Impact of Mining Activities on the Suspended Sediment Composition}

The high proportions in $\mathrm{Mg}$ and Si content measured in SPM correspond to the geochemical signature of the exploited saprolitic layers, with $\mathrm{Mg}$ and $\mathrm{Si}$ concentrations being strongly correlated $\left(R^{2}=0.920\right)$. These enrichments result from weathering phenomena occuring in the upper layers, which lead to the formation of laterites [49,50]. Moreover, the Mg concentrations measured in SPM cannot have a predominantly marine origin (aragonite) since the correlation coefficients between $\mathrm{Ca}$ and $\mathrm{Mg}$ are not significant, except for Dumbéa Bay where biological activity seems more important than in the other two bays. Studies of sedimentary records $[19,26]$ demonstrate the effects of the weathering mechanisms on the marine environment in terms of SPM composition.

The highest Mg and Si concentrations were measured in St Vincent Bay, which is supplied with SPM from the active mining of the La Tontouta basin. There are few differences between Dumbéa and Boulari bays.

\subsubsection{Boulari Bay}

The strong correlation obtained between all the major and metal elements $\left(R^{2}>0.982\right)$, except for $\mathrm{Mg}$, is probably the consequence of the erosion of former mining sites, which have been abandoned for more than 30 years. Indeed, all the correlated elements are present in both the metals-bearing garnierite and the exploitable laterites as the result of the weathering of the ultra-mafic rocks. As for $\mathrm{Mg}$ (with Si and Ca), this element is subject to a preferential leaching [50,61], and consequently, the concentration of $\mathrm{Mg}$ decreases in the upper lateritic non exploitable layers that are washed away by surface runoff into the lagoon.

Concerning $\mathrm{Mg}$, XRD analysis showed that Mg-bearing minerals may be carbonates or clay minerals. The lack of $\mathrm{Ca} / \mathrm{Mg}$ correlation and the relatively similar concentrations of these two minerals suggested that $\mathrm{Mg}$ is mainly bound to an Mg clay mineral devoid of metals such as talc (Table 9). The good correlation between $\mathrm{Ca}$ and metal may be surprising because these elements are not the main metal-bearing minerals transported from the soils (Table 6). Two reasons may explain this correlation: (i) co-precipitation of dissolved metals with coral reef $\mathrm{CaCO}_{3}[26,62]$, suggesting these could have been formed from inputs of SPM from former mines from the beginning of the 20th century until the late 1970s; (ii) Ca is also present in the metal-bearing iron hydroxides and clay minerals (Table 11 and Figure 6). 
The high content of metals in SPM collected at the beginning of the sampling period (21 to 22 November) can be correlated with the presence of a large amount of fine particles as suggested by both the Junge parameter $(s=3.7)$ and the high turbidity (4.7 FTU) (Figure 3$)$. In the days that followed, the increase in the mean diameter $\left(D_{50}\right)$ and the decrease in the Junge parameter $s$ demonstrated that a fast physical and chemical aggregation occurred from 24 to 26 November. This aggregation, probably with organic matter, was accompanied by a significant solid dilution in the terrigenous metal concentrations in the SPM (Figure 4). This reduction in the metal concentration was highlighted by the sharp decrease in the distribution coefficients $\left(K_{d}\right)$ of the lateritic metal nickel (Figure 7). Later, aggregates became finer (Figure 3) with a higher specific surface area, and relatively stable concentrations in metals ( 28 November to 7 December, Figure 7). From 8 December onwards, the flux of trapped SPM was fairly constant; however, a drastic increase in metal concentrations was observed. These results suggest that sedimentation resulted mostly from settling of small particles $(\varnothing<10 \mu \mathrm{m})$.

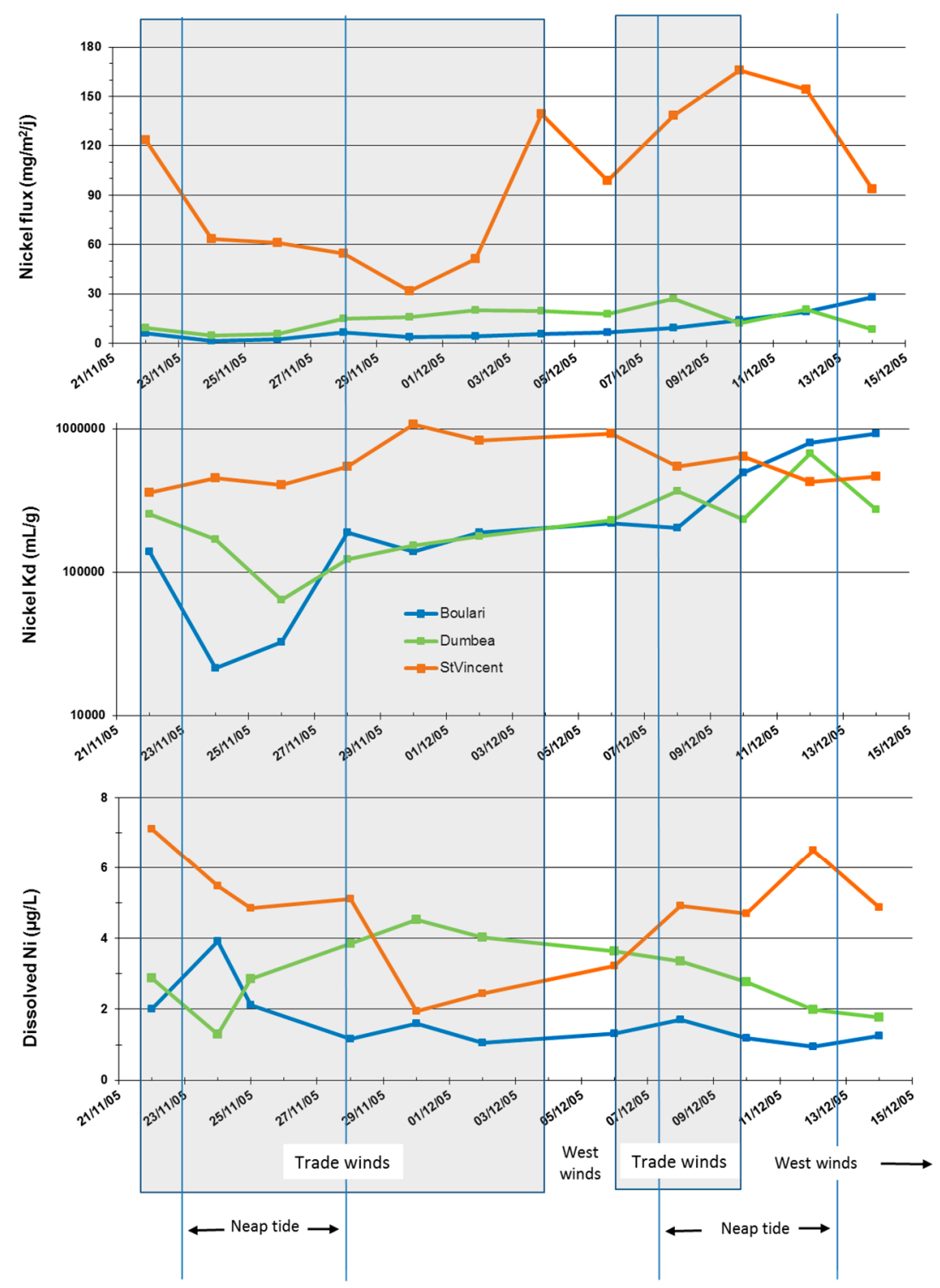

Figure 7. Particulate Ni flux, distribution constant $\left(K_{d}\right)$ of Ni and dissolved concentration of Ni for Boulari, Dumbéa and St Vincent bays over the study period (21 November to 14 December 2005), $3 \mathrm{~m}$ above the seabed. 


\subsubsection{Dumbéa Bay}

A strong correlation was observed between the metals and the major elements $\mathrm{Si}$ and Fe. For Mg, no correlation was found with the other analysed elements (Table 9). Mg concentrations were similar to those measured in Boulari Bay's SPM but two times lower than the ones observed in St Vincent Bay. This can be interpreted as a low contribution of smectite as shown by the XRD determinations (Figure 5). Regarding Ca, its concentrations in Dumbéa Bay were much higher than in Boulari Bay and is likely to be generated by strong resuspension of carbonated debris from numerous coral reef colonies, by trade winds upstream of the sampling area (Table 8). Indeed, Dumbéa Bay shelters fringing reefs and corals both, alive and dead, on its sea bottom which constitute an important source of carbonates compared to the Coulée River mouth [36]. The metals were only slightly correlated to Ca and this probably reflects the low residence time of seawaters in this bay [63].

The concentrations of metals determined in the SPM were averaged at the beginning of the study period (22 November), and correlated well with the presence of fine particles $(s=3.45)$; in spite of this, the turbidity remained low (1.3 FTU) (Figures 3 and 4). From the 24 of November onwards, the strong increase in median diameter $\left(\mathrm{D}_{50}>75 \mu \mathrm{m}\right)$ and reduction in the Junge parameter $(s<3.36)$ preceded a strong sedimentation (Figure 3); this increase in particle size led to a reduction in the metal concentrations in the SPM, a phenomenon identified by the decline in the metal distribution constants $\left(K_{d}\right)$, for example Nickel (Figure 7).

The concentrations of particulate metals progressively increased with the reduction in turbidity and median diameter of SPM until the end of the study period. This phenomenon was probably due to the increase in the specific surface area of the particles. The turbidity and especially the SPM flux was correlated with the strength and direction of the wind while the bottom currents were quite low. Hence, the increase in the mass of SPM probably corresponded to the resuspension of carbonate particles originating from the fringing coral patches of shallow depth found south-east of the bay and subjected to trade winds, as shown by the significant increase in Ca concentrations observed (Figure 4). Until 11 December, the trade winds may have been the cause of occasional deposition of aeolian nickel dust generating the high metal concentration increase observed in the SPM; this dust is generated by the nickel processing SLN plant (Figure 1) located on the south-east coast of Dumbéa Bay. After that date, the westerly winds that blew until the end of the study period were probably responsible for the decrease in the concentration of metals (Figures 2 and 4).

\subsubsection{St Vincent Bay}

Except for $\mathrm{Ca}$, a strong correlation was also observed between the metals and the major elements ( $\mathrm{Si}, \mathrm{Fe}$ and $\mathrm{Mg}$ ) but the values of $\mathrm{R}^{2}$ were slightly lower than in Boulari Bay (Table 9). The correlation is well explained by the present-day mining extraction of less weathered lateritic layers enriched with metals. The main difference with Boulari Bay is that a high correlation was observed between $\mathrm{Mg}$ and the metals and a lower correlation between Ca and the metals. XRD from St Vincent Bay samples showed the presence of smectite (Figure 5) not observed in Boulari Bay's SPM, which might explain the difference. SPM in St Vincent Bay was also enriched in Fe and Si (and Al, not presented in this paper) compared to the other bays, which might be explained by the higher proportion of clays. The high concentrations of Ca suggested a sizeable contribution of resuspended carbonates as a result of the regular effect of the winds in this shallow bay. Besides this, a significant proportion of former resuspended coral reef debris could explain the lower correlation of Ca with the metals in St Vincent Bay.

Over the study period, some variations were observed in the metal concentrations present in the SPM with no major trends evident and of smaller amplitude than in the 2 other bays. However, a clear correlation between $K_{d}$ values and the tide was detected, with smaller $K_{d}$ at neap tides than at spring tides (Figure 7). During spring tides, the resuspension of fine particles and subsequent adsorption of metals ( $K_{d}$ values) increased. Nevertheless, resuspension was not only caused by tides, but also by the wind regimes. Indeed, on the 24 November, an increase in turbidity and in the Junge parameter 
and a decrease in $\mathrm{D}_{50}$ highlighted a resuspension event at the end of a spring tide period, due to the re-establishment of trade winds (Figures 2, 3 and 7). Aggregation of suspended particles and subsequent deposition followed, but was interrupted by a short resuspension event on the 2 December, likely due to the combined effect of spring tides and waves generated by the wind. This resuspension likely induced the high amount of SPM collected on 4 December. Immediately after a short period of trade winds, aggregation and deposition were observed from 8 December during weak westerly and variable winds, hence promoting the deposition of aggregates.

\subsection{Origin of the Minerals}

All of the detrital minerals detected were previously described [50] from the weathering profiles of the plateaus. The predominance of clay minerals in St Vincent Bay and Boulari Bay may be attributed to the presence of, respectively, actual and former open cast mines in their watershed which erode the deeper lateritic horizons where clay minerals are for the most part located.

In all the lagoon sediments, carbonates minerals (calcite, aragonite, $\mathrm{Mg}$ carbonate), absent in the riverine sediments, provide evidence of sediment resuspension [26]. Other authors [64] also showed that in the different typical bottoms of the lagoon, more than $80 \%$ of total sedimentation was linked to deposition of resuspended benthic material. Suspended sediments present in St Vincent Bay contain the same main terrestrial minerals as those detected in the Tontouta River: quartz, goethite, talc, serpentine and smectite. However, smectite and serpentinite may also result from neoformation in the delta area or in the bay itself [26,50,65]; the presence of smectite was higher in St Vincent Bay than in the connected Tontouta River. In tBoulari Bay under trade wind conditions, SPM contained the same minerals as those found in St Vincent Bay except that goethite was more present than clays. During a west wind regime, no clay minerals were detected, and goethite and quartz were the only terrestrial minerals found. During the same period, SPM collected in Dumbéa Bay were characterized by the same minerals as in St Vincent Bay, but clays and goethite contents were lower and samples were dominated by lagoonal material (calcites and aragonite). These results therefore show that the mineralogical composition of suspended sediments in the 3 bays was not strictly related to the composition of sediments transported by their connected rivers. These findings may be due to the presence of authigenic minerals in the bay $[26,36]$ besides detrital particles.

A chemical analysis of a goethite particle referenced as B8A1 (Table 11 and Figure 6) yields similar results to the one given by [50]. Chrysotile (a mineral from the serpentine family) particles forming long acicular tubes were also detected (referenced as C6A17 in Table 11 and Figure 6. This mineral is formed in fractures of the ultrabasites and results from an episode of serpentinisation which concentrates $\mathrm{Ni}$ [50]. Compared to other serpentinites analysed previously [50,60], the analysed chrysotile particle had a comparable chemical composition (Table 11). A particle with a different composition (less $\mathrm{Al}$ and $\mathrm{Mg}$ and more Fe) was also detected (referenced as B8A5 in Table 6 and Figure 6. The composition of this particle is comparable to a poorly crystallized smectite named crypto nontronite [50], which is found in sediments of the deltaic plain and probably originates from diagenesis.

The composition of the particle referenced B7A5 (Table 11 and Figure 6) is more intriguing because of its high Ni content. It could be comparable to a clay mineral like that of a serpentine phase with a high degree of Ni substitution, but such a composition has not yet been reported in New Caledonia. Neoformed serpentine has been identified [26] in the lagoonal sediments of Dumbéa Bay but was not quantified. In addition, the serpentinite was of the Fe (III) type and comparable to the authigenic green phyllosilicates described by Odin et al. [66] in the lagoonal sediments of New Caledonia. Authigenic clay minerals in the Amazon delta have also been described by Michalopoulos and Aller [67], who demonstrated that clay minerals may form rapidly in the sediment pores after liberation of $\mathrm{Si}$ from the diatoms and $\mathrm{Al}$ and $\mathrm{Fe}$ from the oxy-hydroxides derived from the drainage basin. The amount of diatoms or other biogenic silica sources is not known in New Caledonia but their presence has been detected here by TEM. Besides this, goethite is abundant. We therefore support the idea that the high amount of $\mathrm{Ni}$ in the clay particle B7A5 resulted from $\mathrm{Ni}$ incorporation in the 
structure of the clay during diagenesis. This statement implies that part of the dissolved Ni in the lagoon may be fixed by minerals, which limit its dissemination.

\section{Conclusions}

Our approach combining mineralogy, geochemistry and hydrodynamics allowed us to determine how driving factors are affecting the dynamics of particulate matter in lagoonal ecosystems influenced by the mining industry (Table 12). During the dry season, the concentrations of metal present in the water of the 3 bays were principally governed by the alternating south-easterly (trade winds) and westerly winds. The spring and neap tides do not appear to play a major role in the conditions observed during the study period, except in St Vincent Bay. The driving forces behind the resuspension of particles were similar in Boulari and Dumbéa bays, but clearly differed in St Vincent Bay. This difference can be attributed to the shallow depths present in the bay, the intense mixing and the resulting aggregation mechanisms. This resuspension phenomenon was responsible for the distribution of dissolved and particulate metals in the water column $\left(K_{d}\right)$.

In St Vincent Bay, during periods of intense resuspension, the adsorption of Ni onto many particles was promoted and reversely, the concentration of dissolved nickel increased during the sedimentation phase as a result of calm meteorological conditions. In Boulari Bay, the sedimentation stages and constant Ni concentrations coincided with west weak wind periods allowing the coastal waters blocked along the coast-line by the long trade winds periods to flow off-shore. This phenomenon was reversed in Dumbéa Bay where the redissolution of Ni seemed to be higher during the period of resuspension of the particles richer in carbonates. Table 12 summarizes the effects of the different wind regimes in these 3 bays during the dry season.

Table 12. Effects of wind regimes on the dynamics of the particulate matter in lagoonal ecosystems influenced by the mining industry in New-Caledonia.

\begin{tabular}{clll}
\hline Bay & \multicolumn{1}{c}{$\begin{array}{c}\text { Trade Wind Regime } \\
\text { (5-10 Knots) }\end{array}$} & $\begin{array}{c}\text { Light West Wind } \\
\text { Regime (<5 Knots) }\end{array}$ & Coastal Breeze Regime (<5 Knots) \\
\hline \multirow{3}{*}{ Boulari Bay } & $\begin{array}{l}\text { Off-shore water inputs, } \\
\text { resuspension of SPM } \\
\text { transported eastwards and } \\
\text { blocked, settling in-shore }\end{array}$ & $\begin{array}{l}\text { Drainage of blocked } \\
\text { coastal waters toward } \\
\text { off-shore (westward), } \\
\text { SPM aggregation and } \\
\text { sedimentation }\end{array}$ & $\begin{array}{l}\text { Settling of a benthic turbid layer } \\
\text { and westwards transport of SPM: } \\
\text { increase in metal fluxes (dissolved } \\
\text { and particulate) }\end{array}$ \\
\hline \multirow{3}{*}{ Dumbéa Bay } & $\begin{array}{l}\text { Resuspension of SPM rich in } \\
\text { carbonates debris, followed } \\
\text { by sedimentation }\end{array}$ & $\begin{array}{l}\text { Off-shore water inputs } \\
\text { low both in SPM and } \\
\text { metal content }\end{array}$ & $\begin{array}{l}\text { Sedimentation of SPM and } \\
\text { reduction in metal fluxes } \\
\text { (dissolved and particulate) }\end{array}$ \\
\hline \multirow{5}{*}{ St Vincent Bay } & $\begin{array}{l}\text { Intense resuspension of SPM } \\
\text { by the tide and winds over } \\
\text { shallow water, then settling } \\
\text { and high particulate metal flux }\end{array}$ & $\begin{array}{l}\text { Sedimentation of a small } \\
\text { fraction of SPM, } \\
\text { reduction in metal fluxes }\end{array}$ & $\begin{array}{l}\text { Important persistence of } \\
\text { resuspension of SPM: high metal } \\
\text { fluxes (dissolved and particulate) }\end{array}$ \\
\hline
\end{tabular}

In terms of environmental impact, the amounts of lateritic particles that have accumulated over time can modify the geochemical equilibriums in the water column, particularly in shallow and sheltered bays. Reducing the concentration of SPM injected into the lagoon seems essential to limit the effects of the bio-accumulation in exposed marine organisms, for example, dissolved $\mathrm{Ni}$, up to $7 \mu \mathrm{g} \cdot \mathrm{L}^{-1}$ in St Vincent Bay (vs. $2 \mu \mathrm{g} \cdot \mathrm{L}^{-1}$ in Boulari Bay) correspond to the higher particulate Ni fluxes of $170 \mathrm{mg} \cdot \mathrm{m}^{-2} \cdot \mathrm{d}^{-1}$ observed in the bay.

Acknowledgments: This work was supported by the Institut de Recherche pour le Développement. The authors are grateful to the diving IRD team (J.L. Menou, E. Folcher and C. Jeoffroy), the R/V Captains (M. Clarque, S. Tereua and N. Colombani), Alain Belhandouz and Jean Pierre Lamoureux for their assistance in the field trips and sample collections.

Author Contributions: Jean Michel Fernandez, Jean Dominique Meunier and Sylvain Ouillon conceived and designed the experiments; Jean Michel Fernandez, Benjamin Moreton performed the experiments; 
Jean Michel Fernandez, Benjamin Moreton, Pascal Douillet, Olivier Grauby, Jean Dominique Meunier and Sylvain Ouillon analysed the data; Jean Michel Fernandez, Jean Dominique Meunier and Sylvain Ouillon wrote the paper.

Conflicts of Interest: The authors declare no conflict of interest.

\section{References}

1. Labrosse, P.; Fichez, R.; Farman, R.; Adams, T. New Caledonia. In Seas at the Millenium, an Environmental Evaluation; Sheppard, C., Ed.; Elsevier: Amsterdam, The Netherlands, 2000; Volume 2, pp. 723-736.

2. Pandolfi, J.M.; Bradbury, R.H.; Sala, E.; Hughes, T.P.; Bjorndal, K.A.; Cooke, R.G.; McArdle, D.; McClenachan, L.; Newman, M.J.H.; Paredes, G.; et al. Global trajectories of the long-term decline of coral reef ecosystems. Science 2003, 301, 955-958. [CrossRef] [PubMed]

3. Doney, S.C. The growing human footprint on coastal and open-ocean biogeochemistry. Science 2010, 328, 1512-1516. [CrossRef] [PubMed]

4. Burke, L.; Reytar, K.; Spalding, M.; Perry, A. Reefs at Risk Revisited; World Resources Institute: Washington, DC, USA, 2011; Available online: http://pdf.wri.org/reefs_at_risk_revisited.pdf (accessed on 3 January 2017).

5. Maina, J.; McClanahan, T.R.; Venus, V.; Ateweberhan, M.; Madin, J. Global gradients of coral exposure to environmental stresses and implications for local management. PLoS ONE 2011, 6, e23064. [CrossRef] [PubMed]

6. Brodie, J.E.; Kroon, F.J.; Schaffelke, B.; Wolanski, E.C.; Lewis, S.E.; Devlin, M.J.; Bohnet, I.C.; Bainbridge, Z.T.; Waterhouse, J.; Davis, A.M. Terrestrial pollutant runoff to the Great Barrier Reef: An update of issues, priorities and management responses. Mar. Poll. Bull. 2012, 65, 81-100. [CrossRef] [PubMed]

7. De'ath, G.; Fabricius, K.E.; Sweatman, H.; Puotinen, M. The 27-year decline of coral cover on the Great Barrier Reef and its causes. PNAS 2012, 109, 17995-17999. [CrossRef] [PubMed]

8. Erftemeijer, P.L.A.; Riegl, B.; Hoeksema, B.W.; Todd, P.A. Environmental impacts of dredging and other sediment disturbances on corals: A review. Mar Poll. Bull. 2012, 64, 1737-1765. [CrossRef] [PubMed]

9. Morrison, R.J.; Denton, G.R.W.; Bale Tamata, U.; Grignon, J. Anthropogenic biogeochemical impacts on coral reefs in the Pacific Islands-An overview. Deep-Sea Res. II 2013, 96, 5-12. [CrossRef]

10. Myers, N.; Mittermeier, R.A.; Mittermeier, C.G.; da Fonseca, G.A.B.; Kent, J. Biodiversity hotspots for conservation priorities. Nature 2000, 403, 853-858. [CrossRef] [PubMed]

11. Alongi, D.M. Present state and future of the world's mangrove forests. Environ. Conserv. 2002, 29, 331-349. [CrossRef]

12. Bouchet, P.; Lozouet, P.; Maestrati, P.; Heros, V. Assessing the magnitude of species richness in tropical marine environments: Exceptionally high numbers of molluscs at a New Caledonia site. Biol. J. Linn. Soc. 2002, 75, 421-436. [CrossRef]

13. Nagelkerken, I.; Blaber, S.J.M.; Bouillon, S.; Green, P.; Haywood, M.; Kirton, L.G.; Meynecke, J.O.; Pawlik, J.; Penrose, H.M.; Sasekumar, A.; et al. The habitat function of mangroves for terrestrial and marine fauna: A review. Aquat. Bot. 2008, 89, 155-185. [CrossRef]

14. Adjeroud, M.; Fernandez, J.M.; Caroll, A.G.; Harrison, P.L.; Penin, L. Spatial patterns and recruitment processes of coral assemblages among contrasting environmental conditions in the southwestern lagoon of New Caledonia. Mar. Poll. Bull. 2010, 61, 375-386. [CrossRef] [PubMed]

15. Losfeld, G.; L'Huillier, L.; Fogliani, B.; Jaffré, T.; Grison, C. Mining in New Caledonia: Environmental stakes and restoration opportunities. Environ. Sci. Pollut. Res. 2015, 22, 5592-5607. [CrossRef] [PubMed]

16. Hédouin, L.; Bustamante, P.; Fichez, R.; Warnau, M. The tropical brown alga Lobophora variegate as a bioindicator of mining contamination in the New Caledonia lagoon: A field transplantation study. Mar. Environ. Res. 2008, 66, 438-444. [CrossRef] [PubMed]

17. Metian, M.; Bustamante, P.; Hédouin, L.; Warnau, M. Accumulation of nine metals and one metalloid in the tropical scallop Comptopallium radula from coral reefs in New Caledonia. Environ. Pollut. (Oxford, UK) 2008, 152, 543-552. [CrossRef] [PubMed]

18. Hédouin, L.; Bustamante, P.; Churlaud, C.; Pringault, O.; Fichez, R.; Warnau, M. Trends in concentrations of selected metalloid and metals in two bivalves from the SW lagoon of New Caledonia. Ecotoxicol. Environ. Saf. 2009, 72, 372-381. [CrossRef] [PubMed] 
19. Debenay, J.P.; Fernandez, J.M. Benthic foraminifera records of complex anthropogenic environmental changes combined with geochemical data in a tropical bay of New Caledonia. Mar. Poll. Bull. 2009, 59, 311-322. [CrossRef] [PubMed]

20. Bonnet, X.; Briand, M.; Brischoux, F.; Letourneur, Y.; Fauvel, T.; Bustamante, P. Anguilliform fish reveal large scale contamination by mine trace elements in the coral reefs of New Caledonia. Sci. Total Environ. 2014, 470-471, 876-882. [CrossRef] [PubMed]

21. Cuif, M.; Kaplan, D.M.; Lefèvre, J.; Faure, V.M.; Caillaud, M.; Verley, P.; Vigliola, L.; Lett, C. Wind-induced variability in larval retention in a coral reef system: A biophysical modelling study in the South-West Lagoon of New Caledonia. Prog. Oceanogr. 2014, 122, 105-115. [CrossRef]

22. Gilbert, A.; Heintz, T.; Hoeksema, B.W.; Benzoni, F.; Fernandez, J.M.; Fauvelot, C.; Andrefouet, S. Endangered New Caledonian endemic mushroom coral Cantharellus noumeae in turbid, metal-rich, natural and artificial environments. Mar. Poll. Bull. 2015, 100, 359-369. [CrossRef] [PubMed]

23. Heintz, T.; Haapkylä, J.; Gilbert, A. Coral health on reefs near mining sites in New Caledonia. Dis. Aquat. Org. 2015, 115, 165-173. [CrossRef] [PubMed]

24. Dugas, F. La sedimentation en baie de St Vincent (Côte ouest de la Nouvelle-Caledonie). In Cah. ORSTOM, ser. Géol.; Office de la recherche scientifique et technique outre-mer (ORSTOM): Paris, France, 1974; Volume VI, pp. 41-62.

25. Bird, E.C.F.; Dubois, J.P.; Iltis, J.A. The Impact of Opencast Mining on the Rivers and Coasts of New Caledonia; The United Nation University: Shibuya, Japan, 1984; Available online: http:/ /archive.unu.edu/unupress / unupbooks/80505e/80505E00.htm (accessed on 9 May 2017).

26. Ambatsian, P.; Fernex, F.; Bernant, M.; Parron, C.; Lecolle, J. High metal inputs to close seas: The New-Caledonia Lagoon. J. Geochem. Explor. 1997, 59, 59-74. [CrossRef]

27. Fernandez, J.-M.; Ouillon, S.; Chevillon, C.; Douillet, P.; Fichez, R.; Le Gendre, R. A combined modelling and geochemical study of the fate of terrigenous inputs from mixed natural and mining sources in a coral reef lagoon (New Caledonia). Mar. Poll. Bull. 2006, 52, 320-331. [CrossRef] [PubMed]

28. Fichez, R.; Adjeroud, M.; Bozec, Y.M.; Breau, L.; Chancerelle, Y.; Chevillon, C.; Douillet, P.; Fernandez, J.M.; Frouin, P.; Kulbicki, M.; et al. A review of selected indicators of particle, nutrient and metal input in coral reef lagoon systems. Aquat. Living Res. 2005, 18, 125-147. [CrossRef]

29. Grenz, C.; Le Borgne, R.; Fichez, R.; Torreton, J.P. Tropical lagoon multidisciplinary investigations: An overview of the PNEC New Caledonia pilot site. Mar. Poll. Bull. 2010, 61, 267-268. [CrossRef] [PubMed]

30. A collective of 75 authors. Atlas de la Nouvelle Calédonie, IRD ed.; Institut de Recherche pour le Développement (IRD): Marseille, France, 2013; ISBN: 978-2-7099-1740-7.

31. Breau, L. Extractions Séquentielles et Analyses de Métaux dans une Carotte de Sédiments Lagonaires Datée: Mise en Evidence de L'évolution des Apports Terrigènes Liée aux Activités Humaines au Cours des 150 Dernières Années. Master's Thesis, University Aix-Marseille II, Marseille, France, 1998.

32. Magand, O. Contribution à la Modélisation du Transport de la Matière Particulaire dans le Lagon Sud-Ouest de Nouvelle-Calédonie: Etude des flux, Détermination des Signatures Minéralogiques et Evolution Spatiale. Master's Thesis, University Perpignan, Perpignan, France, 1998.

33. Magand, O. Recherche et Définition des Signatures Géochimiques (Métaux Lourds et Lanthanides) des Sources Terrigènes du Lagon Sud-Ouest de Nouvelle-Calédonie. Master's Thesis, University Aix-Marseille II, Marseille, France, 1999.

34. Fernandez, J.-M.; Moreton, B.; Fichez, R.; Breau, L.; Magand, O.; Badie, C. Advantages of combining ${ }^{210} \mathrm{~Pb}$ and geochemical signature determinations in sediment record studies, application to coral reef lagoon environments. In Environmental Changes and Radioactive Tracers, IRD ed.; Fernandez, J.-M., Fichez, R., Eds.; Institut de Recherche pour le Développement (IRD): Paris, France, 2002; pp. 187-200.

35. Moreton, B.M.; Fernandez, J.-M.; Dolbecq, M.B.D. Development of a field preconcentration/elution unit for routine determination of dissolved metal concentrations by ICP-OES in marine waters: Application for monitoring of the New Caledonia lagoon. Geostand. Geoanal. Res. 2009, 33, 205-218. [CrossRef]

36. Ouillon, S.; Douillet, P.; Lefebvre, J.P.; Le Gendre, R.; Jouon, A.; Bonneton, P.; Fernandez, J.M.; Chevillon, C.; Magand, O.; Lefèvre, J.; et al. Circulation and suspended sediment transport in a coral reef lagoon: The southwest lagoon of New Caledonia. Mar. Poll. Bull. 2010, 61, 269-296. [CrossRef] [PubMed] 
37. Fichez, R.; Chifflet, S.; Douillet, P.; Gérard, P.; Gutierrez, F.; Jouon, A.; Ouillon, S.; Grenz, C. Biogeochemical typology and temporal variability of lagoon waters in a coral reef ecosystem subject to terrigeneous and anthropogenic inputs (New Caledonia). Mar. Poll. Bull. 2010, 61, 309-322. [CrossRef] [PubMed]

38. Douillet, P. Tidal dynamics of the south-west lagoon of New Caledonia: Observations and 2D numerical modelling. Oceanol. Acta 1998, 21, 69-79. [CrossRef]

39. Douillet, P.; Ouillon, S.; Cordier, E. A numerical model for fine suspended sediment transport in the south-west lagoon of New-Caledonia. Coral Reefs 2001, 20, 361-372. [CrossRef]

40. Jouon, A.; Lefebvre, J.P.; Douillet, P.; Ouillon, S.; Schmied, L. Wind wave measurements and modelling in a fetch-limited semi-enclosed lagoon. Coast. Eng. 2009, 56, 599-608. [CrossRef]

41. Andréfouët, S.; Cabioch, G.; Flamand, B.; Pelletier, B. A reappraisal of the diversity of geomorphological and genetic processes of New Caledonian coral reefs: A synthesis from optical remote sensing, coring and acoustic multibeam observations. Coral Reefs 2009, 28, 691-707. [CrossRef]

42. Lillie, A.R.; Brothers, R.N. The geology of New-Caledonia. N. Zeal. J. Geol. Geophys. 1970, 13, $159-167$. [CrossRef]

43. Paris, J.P. Les Ressources Minérales de Nouvelle-Calédonie; Mémoire 113, Bureau de Recherches Géologiques et Minières (BRGM): Orléans, France, 1981.

44. Antheaume, B. Chronique de l'Atlas de la Nouvelle-Calédonie, un bilan méthodologique et critique. Cahiers ORSTOM. Série Schum 1981, 18, 389-398.

45. Paris, J.P. Gîtes minéraux et substances utiles. In Atlas de Nouvelle-Calédonie; Sautter, G., Ed.; ORSTOM: Paris, France, 1981.

46. Perrier, N.; Ambrosi, J.P.; Colin, F.; Gilkes, R.J. Biogeochemistry of a regolith: The new Caledonian Koniambo ultramafic massif. J. Geochem. Explor. 2006, 88, 54-58. [CrossRef]

47. Dublet, G.; Fandeur, D.; Juillot, F.; Morin, G.; Ambrosi, J.P.; Fritsch, E.; Brown, G.E., Jr. Ni speciation in a New Caledonian lateritic regolith: A quantitative X-ray absorption spectroscopy investigation. Geochim. Cosmochim. Acta 2012, 95, 119-133. [CrossRef]

48. Dublet, G.; Juillot, F.; Morin, G.; Fritsch, E.; Noel, V.; Brest, J.; Brown, G.E., Jr. XAS evidence for Ni sequestration by siderite in a latéritic Ni-deposit from New Caledonia. Am. Miner. 2014, 99, 225-234. [CrossRef]

49. Dublet, G.; Juillot, F.; Morin, G.; Fritsch, E.; Fandeur, D.; Brown, G.E., Jr. Goethite aging explains Ni depletion in upper units of ultramafic lateritic ores. Geoch. Cosmoch. Acta 2015, 160, 1-15. [CrossRef]

50. Trescases, J.J. L'évolution Geochimique Supergène des Roches Ultrabasiques en Zone Tropicale. Formation des Gisements Nickélifères de Nouvelle-Calédonie. Ph.D. Thesis, University Louis Pasteur, Strasbourg, France, 1973.

51. Pesin, E.; Blaize, S.; Lacoste, D. Atlas Climatique de la Nouvelle Calédonie; Météo France: Nouméa, New Caledonia, 1995.

52. Baltzer, F.; Trescases, J.J. Erosion, transport et sédimentation liés aux cyclones tropicaux dans les massifs d'ultrabasites de Nouvelle-Calédonie. Cahiers ORSTOM Série Géologie III 1973, 2, 221-244.

53. Dugas, F.; Debenay, J.P. Carte Sédimentologique et carte Annexe du Lagon de Nouvelle Calédonie au 1/50000—Mont Dore, Tontouta, Prony, Nouméa; Notices explicatives n 76, 86, 91 and 95; ORSTOM: Paris, France, 1982.

54. Heussner, S.; Ratti, C.; Carbonne, J. The PPS3 times series sediment trap and the trap sample processing techniques used during the ECOMARGE experiment. Cont. Shelf Res. 1990, 10, 943-958. [CrossRef]

55. Jouon, A.; Ouillon, S.; Douillet, P.; Lefebvre, J.P.; Fernandez, J.-M.; Mari, X.; Froidefond, J.M. Spatio-temporal variability in suspended particulate matter concentration and the role of aggregation on size distribution in a coral reef lagoon. Mar. Geol. 2008, 256, 36-48. [CrossRef]

56. Lefebvre, J.-P.; Ouillon, S.; Vinh, V.D.; Arfi, R.; Panche, J.-Y.; Mari, X.; Thuoc, C.V.; Torreton, J.P. Seasonal variability of cohesive sediment aggregation in the Bach Dang-Cam Estuary, Haiphong (Vietnam). Geo-Mar. Lett. 2012, 32, 103-121. [CrossRef]

57. Mobley, C.D. Light and Water Radiative Transfer in Natural Water; Academic Press: San Diego, CA, USA, 1994.

58. Pinet, S.; Martinez, J.-M.; Ouillon, S.; Lartiges, B.; Villar, R.E. Variability of apparent and inherent optical properties of sediment-laden waters in large river basins-Lessons from in situ measurements and bio-optical modeling. Opt. Express 2017, 25, A283-A310. [CrossRef] [PubMed]

59. Cliff, G.; Lorimer, G.W. The quantitative analysis of thin specimens. J. Microsc. 1975, 103, 203-207. [CrossRef] 
60. Manceau, A.; Calas, G. heterogneous distribution of nickel in hydrous silicates from New Caledonia ore deposits. Am. Miner. 1985, 70, 549-558.

61. Pelletier, B. Serpentines in Nickel Silicate Ore from New-Caledonia. In Proceedings of the PublicationsAustralasian Institute of Mining and Metallurgy, Kalgoolie, Australia, 27-29 November 1996; Volume 27-29, pp. 197-206.

62. Wartel, M.; Skirer, M.; Auger, T.; Boughriet, A. Interaction of manganese II with carbonates in sea water: Assessment of the solubility product of $\mathrm{MnCO}_{3}$ and $\mathrm{Mn}$ distribution coefficient between the liquid phase and $\mathrm{CaCO}_{3}$ particles. Mar. Chem. 1990, 29, 99-117. [CrossRef]

63. Jouon, A.; Douillet, P.; Ouillon, S.; Fraunié, P. Calculations of hydrodynamic time parameters in a semi-opened coastal zone using a 3D hydrodynamic model. Cont. Shelf Res. 2006, 26, 1395-1415. [CrossRef]

64. Clavier, J.; Chardy, P.; Chevillon, C. Sedimentation of particulate matter in the South-west lagoon of New Caledonia: Spatial and Temporal Patterns. Est. Coast. Shelf Sci. 1995, 40, 281-294. [CrossRef]

65. Baltzer, F. Géodynamique de la Sédimentation et Diagénèse Précoce en Domaine Ultrabasique, Nouvelle-Calédonie; ORSTOM: Paris, France, 1982.

66. Odin, G.S. Green Marine Clays; Elsevier: Amsterdam, The Netherlands, 1988.

67. Michalopoulos, P.; Aller, R.C. Rapid clay mineral formation in Amazon delta sediments: Reverse weathering and oceanic elemental cycles. Science 1995, 270, 614-617. [CrossRef]

(c) 2017 by the authors. Licensee MDPI, Basel, Switzerland. This article is an open access article distributed under the terms and conditions of the Creative Commons Attribution (CC BY) license (http://creativecommons.org/licenses/by/4.0/). 